\title{
Does Corporate Lending by Banks and Finance Companies Differ? Evidence on Specialization in Private Debt Contracting
}

\author{
Mark Carey \\ Mitch Post \\ and \\ Steven A. Sharpe
}

Federal Reserve Board

June 6, 1996

Keywords: private debt, bank loan, finance company, corporate debt JEL Classification: G20, G32

The views expressed herein are the authors' and do not necessarily reflect those of the Board of Governors or the staff of the Federal Reserve System. We would like to acknowledge excellent research assistance provided by Margaret Kyle. Address correspondence to Mark Carey, Mail Stop 180, Federal Reserve Board, Washington, DC 20551. (202) 452-2784 (voice), (202) 452-5295 (fax), mcarey@ frb.gov (email). 
1. Introduction

Much of the recent research on financial contracting and intermediation focuses on the distinction between private and public debt contracts. The central theme of this research concerns why, and to what degree, private market suppliers of credit are better suited than public creditors to finance "information-problematic" borrowers, or all but the least risky and well-known firms. Private market lenders are thought to have stronger incentives or greater ability to monitor borrowers (Diamond 1984, 1991; Fama 1985), or to be better positioned than public creditors to renegotiate contract terms or exercise control rights in the event of a problem (Berlin and Mester 1992; Gorton and Kahn 1993). In addition, a valued reputation enhances private market lenders' ability to make credible commitments to act in good faith should a borrower experience problems (Chemmanur and Fulghieri, 1994).

Perhaps mainly for simplicity, almost all studies to date have analyzed generic intermediaries and private debt ("banks" and "bank loans"). Many important questions arise in corporate finance and financial intermediation, however, if different types of business lenders or private debt contracts are specialized to different borrowers, as practitioners often suggest. Why does specialization arise, and what can be learned about private debt in general by an examination of it? Which lenders and which types of private debt should a given borrower use? Are different capital or funding structures optimal for intermediaries with different lending specialties? How should different kinds of private lending be regulated, if at all? In wholesale restructurings of financial systems, should 
specialization in lending be preserved mainly within a single corporate structure, such as a universal bank, in different organizations, or not at all?

This paper establishes empirically that specialization in private market corporate lending exists. Using a large microdata set with information on individual loans, we compare private market business lending by finance companies to that by banks. ${ }^{1}$ We test the hypothesis that their lending is effectively identical, with two specific alternative hypotheses in mind. One is that their borrowers differ along an asymmetric-information dimension, as implied by the strand of literature that posits that banks in particular are unique in serving information-problematic borrowers (Fama 1985; James 1987; Nakamura 1991 ). Perhaps surprisingly, we fail to reject the null of no difference. Given the extensive evidence that banks serve information-problematic borrowers, the implication is that intermediaries in general are special with respect to information, not banks in particular. ${ }^{2}$

A second alternative is that bank and finance company borrowers differ in ex ante observable risk, such as leverage. Practitioners believe that finance company borrowers

\footnotetext{
${ }^{1}$ Finance companies are an excellent vehicle for comparison because, as described in section II, they provide a large volume of business credit, are thought to compete directly with banks in corporate lending, are lightly regulated relative to banks, and have interesting capital and corporate structures.

${ }^{2}$ Other recent studies supporting this conclusion include Preece and Mullineaux (1 994) and Billett, Flannery and Garfinkel (1995), who find no difference in the reaction of borrower share prices to announcements of loans by banks and nonbanks, and Carey, Prowse, Rea and Udell (1993), who present evidence that insurance companies' private placement portfolios represent a form of information-intensive lending. The only recent studies examining finance companies or competition between finance companies and banks, of which we are aware, are Simonson (1994), Remolona andWulfekuhler(1992), and Gorton and Pennacchi (1993).
} 
are riskier but are silent on whether the risk is observable or is associated with information problems. We reject the null of no difference in borrower characteristics in favor of this alternative hypothesis.

Evidence on these matters is drawn both from simple summary statistics and from estimation of logit models that predict whether a borrower is served by a bank or a finance company. Common proxies for information problems (firm size, R\&D to sales, market-tobook value, etc.) and observable risk (leverage, interest coverage, etc.) appear as explanatory variables. ${ }^{3}$ To buttress the logit results, and to provide a more complete portrait of competition and specialization, we also characterize the distributions of many of these variables for each lender type. In addition, we provide statistics about loan purposes, types, spreads, and some nonprice terms. ${ }^{4}$

Lending specialization by observable risk is not immediately explainable by modern theories of intermediation. We propose and offer evidence related to three explanations, all of which have some support in practitioner lore. One obvious possibility is regulation:

${ }^{3}$ This is a variant of a method used to study whether and why a firm borrows publicly or privately or to study the mix of public and private debt in firm capital structures (MackieMason 1990; Houston and James 1995a). A different method for addressing the same issues involves comparisons of the sensitivity of investment to cash flow for borrowers with and without private debt in their capital structure (Fazzari, Hubbard and Peterson 1987; Houston and James 1995b). Calomiris and Himmelberg (1995) recently provided a new type of evidence by examining correlations between accounting measures and firms' costs of public issuance, although their paper is focused on the extent of information problems posed by different public firms.

${ }^{4}$ We do not focus on spreads, or model them in any detail. Construction of a model of spreads that would be useful for the issues at hand is a large task that is beyond the scope of this paper. 
perhaps bank regulators, in their efforts to limit excessive risk-taking by banks, effectively limit banks' ability to serve high-risk borrowers. A second explanation emphasizes the distinction between control and information problems. For example, debtholderstockholder conflicts associated with leverage may arise even at widely followed firms, and perhaps banks and finance companies specialize in low- and high-control-problem firms, respectively. The main difficulty with this explanation is it does not really address why different institutional types arise. Our third explanation focuses on reputational factors. Even loans to lower-risk borrowers are frequently renegotiated (Kwan and Carleton 1993; Beneish and Press 1994) and such borrowers rely on lenders to be reasonable, that is, to refrain from extracting maximum rents when a covenant waiver or other change in terms is requested. A lender's reputation for reasonableness is thus a valuable asset, one which might be damaged if the lender is observed to frequently force borrowers into liquidation. Reputational costs can be limited by specialization: high risk borrowers are served by lenders known to be tough and unbending, whereas lower-risk borrowers are served by those known to be gentle. As we present no model of this mechanism, we view the explanation as speculative.

We do not present definitive tests of these hypotheses, but are able to shed some light on their realism by close examination of the relationships between lender type and borrower leverage and cash flow and by a finer partition of institutions. For example, we compare the riskiness of lending by U.S. banks, bank-affiliated finance companies, and other finance companies. We find that borrowers at U.S. banks and their affiliated finance 


\title{
Does Corporate Lending by Banks and Finance Companies Differ?
}

\section{Evidence on Specialization in Private Debt Contracting}

\begin{abstract}
--- Abstract ---
This paper establishes empirically that specialization in private-market corporate lending exists, adding a new dimension to the public vs. private debt distinctions now common in the literature on debt contracting and financial intermediation. Using a large database of individual loans, we compare lending by finance companies to that by banks. The evidence implies that it is intermediaries in general that are special in solving information problems, not banks in particular. But lending by the two types of institutions is not identical. Finance companies tend to serve observably riskier borrowers, especially highly leveraged borrowers, although banks and finance companies do compete across the spectrum of borrower risk. The evidence supports both regulatory and reputational explanations for this specialization and perhaps an explanation based on institutional differences in borrower monitoring and control. In passing, we shed light on various theories of debt contracting and intermediation and also present facts about finance companies, which have received little attention.
\end{abstract}


companies are similar in observable risk, while borrowers at bank-affiliated finance companies are less risky than borrowers at other finance companies. On the whole, we believe the results offer some support for all three explanations.

In passing, the analysis provides evidence relevant to a variety of hypotheses about the operation of private debt markets. The hypothesis that easy access to the information in business checking accounts gives banks a unique advantage in monitoring borrowers (Black 1975; Fama 1985; Nakamura 1991) is not supported (at least for the corporate borrowers examined here), as finance companies monitor but do not offer checking accounts. There is some support for the hypothesis that a substantial share of lender liabilities in the form of demandable debt provides lenders with incentives to monitor (Flannery 1994; Calomiris and Kahn 1991) because a significant share of both bank and finance company liabilities are effectively demandable debt. The idea that elements of borrower-lender relationships other than cross-selling are an important factor in private debt contracting (Rajan 1992; Petersen and Rajan 1994; Berger and Udell 1995) is supported in that finance companies appear to have fewer opportunities to cross-sell, but nevertheless appear as the relationship lender in multilender loans in proportion to their share of such loans. The idea that deposit insurance leads banks to take excessive risk even after the restraints of prudential regulation are factored in is not supported, as finance companies make riskier loans but do not have access to deposit insurance. ${ }^{5}$

${ }^{5}$ The idea is not refuted either, as there are other ways to take excessive risks. Interestingly, Flannery (1989) finds that capital regulation may cause banks to prefer loans that are individually less risky even while they prefer larger portfolio risk. We do not address portfolio risk. 
The analysis also has implications for recent narrow banking proposals for restructuring the financial system. In such proposals. existing banks would be split into an insured depository with strict limits on the risk of its investments and an uninsured "finance company." Implicitly adopting the view that all information-intensive intermediaries are the same, proponents point to existing finance companies as evidence that there would be no disruptions to aggregate credit. Our evidence supports the view that extant finance companies do not mimic bank lenders. Without better understanding of the reasons why, it is premature to conclude that narrow banking would have little or no effect on the cost and availability of business credit.

This paper's data include only corporate private debt, not small business or consumer loans. Thus the findings may not apply to the latter, as it is quite possible that contracting problems and lending practices and technologies differ for those sectors.

The remainder of the paper is in seven parts. As characteristics of finance companies are not well known, we provide a profile in section II. In section III we describe the loan microdata, and in section IV we report results of logit models of the choice of banks versus finance companies as lenders. Section $V$ presents comparative statistics on various characteristics of loans, including type, purpose, spreads, and some nonprice terms. Evidence related to the control problem hypothesis regarding why specialization exists also appears in Sections IV and V. Section VI describes the reputational and regulatory hypotheses about why specialization exists and presents evidence. Section VII pulls together the evidence, draws conclusions about the nature of private debt, and 
poses some questions for further research.

\section{An Introduction to the Finance Company Industry}

A finance company is a nondepository financial institution involved primarily in extending credit to business and consumers. ${ }^{6}$ Because finance companies do not collect deposits, they are not constrained by bank regulations (unless affiliated with a bank), but also do not have access to deposit insurance and the discount window, Historically, finance companies have been reputed to make high-interest loans to borrowers turned away by banks and to rely on relatively aggressive measures to ensure repayment. Those close to the industry argue that finance companies use different techniques for controlling risks than do banks and that these techniques are better suited to higher-risk classes of borrowers or different loan purposes.

At the end of 1994 , finance companies had about $\$ 670$ billion in assets, compared to commercial bank assets of about $\$ 3.9$ trillion (table 1). The industry is concentrated, with the twenty largest finance companies holding two-thirds of all assets at the end of 1994. General Electric Capital Corp. (GECC), the largest firm, had assets in excess of $\$ 130$ billion, alone accounting for about one-fifth of industry assets. General Motors Acceptance Corp., Ford Motor Credit, and Chrysler Financial Services together held another 28 percent of industry assets ( $\$ 185$ billion). Another twenty or so firms fall

6 Finance companies include captive financing subsidiaries of nonfinancial corporations, general consumer and business finance companies, leasing companies, and factors. 
between $\$ 5$ and $\$ 30$ billion: beyond that, there are an uncertain number of firms that may be as small as $\$ 30$ million.

Unlike commercial banks, which may only be owned by other banks or by regulated bank holding companies, ownership of finance companies is virtually unrestricted. Indeed, among the largest firms in the industry, only a few are not wholly owned subsidiaries of other firms. The nature of ownership sometimes strongly influences finance companies' operations. Many of the captive finance subsidiaries of manufacturing or commercial firms exist almost solely to promote the sale of their parents' products, although some engage in a broader range of finance. Other finance companies, even though wholly owned, operate essentially as independent lenders and pursue a variety of portfolio strategies. The operations of finance company subsidiaries of domestic or foreign banking organizations may be constrained to some degree by regulation.

Finance companies rely primarily on the capital markets, their parents, or banks for funding. As shown in Table 1, the largest fractions of their finance are from commercial paper, bond and medium-term note issuance. The commercial paper closely resembles demandable debt and may enhance finance companies' incentives to monitor in the same way that banks' short-term liabilities do (Flannery 1994; Calomiris and Kahn 1991). Alternatively, finance companies may issue it mainly to match the rate and maturity characteristics of certain assets.

Finance companies are less leveraged than banks. At the end of 1994, their aggregate equity-to-assets ratio was 11.3 percent, compared to about 8.3 percent for 
commercial banks. Moreover, the finance companies' ratio may understate their true capital position because many of their parents, which have significant other assets, have implicitly or explicitly committed to support their subsidiaries.

The composition of finance companies' business credit portfolios differs substantially from that of banks (table 2). Although total business credit at finance companies, at $\$ 360$ billion, was about 44 percent of bank commercial and industrial (C\&l) loans outstanding, $\$ 227$ billion of this was auto-related or equipment lease financing. Leasing and auto-related finance is a much smaller share of banks' business credit. Banks may beat a competitive disadvantage in these activities relative to the captives, and in addition certain bank regulations limit their participation in equipment leasing.

The fact that a large share of finance company assets are lease-related is consistent with finance companies specializing in relatively high-risk finance. Sharpe (1995) provides evidence that lessees of equipment tend to be riskier than firms that acquire equipment outright, suggesting that lessors are more willing or better suited to bear the additional risk or can better manage it than other lenders.

Although the business credit portfolios of banks and finance companies differ on the whole, the $\$ 111$ billion of "other" finance company business credit shown in table 2 includes the corporate loans in our microdata sample, and here it is not clear that there are any differences. Moreover, practitioners perceive finance companies to be in direct and active competition with banks in providing these loans (Sherman 1993). However, they often argue that finance companies utilize different monitoring and control strategies than 
banks. Finance companies are described as "asset-based" lenders and banks as "cash flow" lenders. In making a loan, an asset-based lender emphasizes collateral as a source of ultimate repayment whereas a cash flow lender relies more heavily on projected cash flow from operations. Asset-based lenders are said to monitor collateral much more closely after a loan is made. ${ }^{7}$

\section{Data}

We analyze a sample of 14,735 loan agreements involving about 5,700 different U.S. business borrowers drawn from the November, 1993 release of Loan Pricing Corporation's (LPC) Dealscan database, which at the time of the draw contained about 18,000 loans made between 1987 and early 1993.8 For the typical loan, the database includes the name and location of the borrower and the names of all lenders party to the loan contract at origination; the type, purpose, amount, and contract date of the loan; and information on price and some nonprice terms. The great majority of the loans are floatingrate, None of the loans are securities from a legal standpoint (data on private placements

${ }^{7}$ Some bank lending groups or affiliates of banks themselves might be asset-based lenders. However, some commercial bankers argue that bank supervisors fail to recognize or understand the distinct nature of asset-based lending and, as a result, may at times inappropriately classify such loans as nonperforming. Banking organizations may therefore be less likely to extend this form of credit.

${ }^{8}$ We estimate that at the end of 1992, loan agreements in the database covered between half and three-quarters of all commercial and industrial loans outstanding by volume, but a far smaller fraction of the number of such loans, as the database contains no small business loans. We exclude from our sample loans to non-U.S. borrowers, the small number made before 1987 or with a missing contract date, and those observations flagged by LPC as being based on unconfirmed information. 
are collected separately), and very few are subordinated to other debt of the borrower. ${ }^{9}$

According to LPC, the great majority of the data were collected from commitment letters and credit agreements drawn from SEC filings. ${ }^{10}$ Especially in more recent years, some data were collected from news reports or through LPC's relationships with major banks. These collection strategies yield a database of medium-size to large loans that are representative of the financing activity of publicly held or larger private firms, with few or no small business loans. The sample selection criteria appear unrelated to correlations between lender identity and loan or borrower characteristics (the primary focus of the empirical work). As shown in Panel A of Table 3, the median full sample loan was for $\$ 30$ million and had a maturity of three years. Loan size was $\$ 250,000$ at the first percentile and $\$ 1.5$ billion at the 99th percentile.

About 56 percent of the loans involve only a single lender at origination, with the remainder involving multiple lenders. A variety of institutional types are represented, including U.S. and foreign commercial banks, savings and loans, finance companies, insurance companies, investment banks, etc. We identified the type of each lender by

${ }^{9}$ A substantial minority of the loan packages or "deals" involved more than one loan "facility" originated by the same borrower on the same date. A typical package might include a line of credit and term loan. In general, we conduct our analysis at the facility level, treating each as a separate loan, because deals involving multiple lenders do not always have the same set of lenders involved in all facilities. All results are robust to conduct of the analysis at the deal level, however.

10 Registered firms are required to disclose information about any financing in excess of 10 percent of their total assets, and while not required to do so, often choose to include the full text of the credit agreement as an attachment to their filing. 
matching names with corporate directory entries and databases maintained by the Federal Reserve. We then divided the lenders into three basic types: banks, finance companies, and other. We also determined the parentage of almost all the finance companies, classifying these into U.S. and foreign bank subsidiaries, nonfinancial corporation subsidiaries, financial corporation subsidiaries, and unknown. Where a loan involves multiple lenders, it is not uncommon for a variety of institutional types to be represented, but by far the most common mix is banks alone. Finance companies were next most frequently represented, being either sole or a joint lender in about 10.5 percent of sample loans. This finance company participation share is relatively constant over the years of the sample, ranging from a low of 8.2 percent in 1987 to a high of 12.7 percent in 1989 .

In cases where a loan involves multiple types of lender, several different classification schemes appear reasonable ex ante. We analyze multiple-lender loans separately from single-lender loans, and throughout the reported analysis we classify any multiple-lender loan involving a finance company in any capacity as a 'finance company loan,' regardless of the mix of other institutional types represented. Results are robust to other classification schemes, however, such as a requirement that a finance company be the lead lender. Of course, classification is unambiguous for the single-lender loans.

We obtained borrower characteristics, such as leverage, by matching their names to firm names in the Compustat database, succeeding for about half the borrowers and 9145 of the loans, as summarized in Panel B of Table 3. ${ }^{11}$ Median loan size and maturity

${ }^{11}$ For use in analysis of bank and finance company loan pricing, where possible we also obtained public bond ratings or equivalents at the time the loan was made. 
for this subsample are not far from full sample values. The median Compustat sample loan was to a firm with $\$ 232$ million in sales and $\$ 219$ million in assets at the end of the fiscal year in which the loan was made. ${ }^{12} \mathrm{~A}$ relatively small number of financial and government borrowers in the full sample were excluded from this sample by construction.

\section{Lender Type Prediction Model Results}

We estimate logit models of the form:

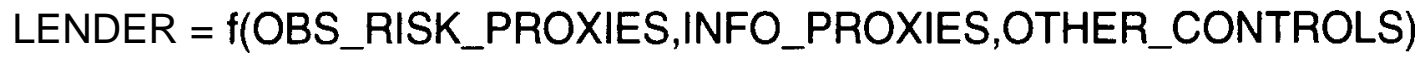

where LENDER takes the value 1 for finance company loans and $O$ for bank loans. ${ }^{13}$ Table 4 provides summary statistics for variables proxying for the borrower's observable risk and the extent of information problems it poses.

Proxies for observable borrower risk include two measures of leverage, three measures of the level of cash flow and one of measure of its volatility, and dummy variables for the stated purpose of the loan. Book leverage is the book value of debt divided by the sum of itself and book equity, whereas market equity replaces book equity in the market leverage measure. Earnings before interest, taxes, depreciation and amortization (EBITDA) appears in the numerator of the three measures of the level of cash flow. Interest expense appears in the denominator of the interest coverage ratio, and total

12 All balance sheet and income statement variables employed in the paper are as of the end of the borrower's fiscal year.

13 Other control variables include dummies for the year of the loan and the industry of the borrower. 
assets and sales in the denominators of the return on assets and return on sales measures, respectively .14 We measure the volatility of cash flow with a Z-score-based measure of the probability of negative cash flow, computed using the five-year mean and standard deviation of EBITDA. Sixteen different stated loan purposes that appear in the database are grouped and represented by four dummies. ${ }^{15}$

We follow the literature in choosing proxies for information or control problems posed by the borrower. Smaller firms are commonly presumed to pose larger information asymmetries; we measure size by the natural logarithms of total assets or sales. The number of years up to the date of the loan that data for the borrower appears in Compustat is another proxy for the extent and history of widely available information about the borrower (Compustat covers all firms traded on the three major exchanges and some others). Firms engaged in extensive R\&D, those with relatively large growth opportunities, and those growing rapidly are thought to be relatively hard to monitor and control. The incentives and opportunities of such firms to expropriate wealth from lenders may shift rapidly (they may be able to rapidly change the riskiness of firm assets, for example). We

14 Interest coverage and return on assets and sales are exceptions to our usual rule of measuring variables as of the end of the fiscal year in which the loan agreement was signed: each is a three-year average, centered on the year of the loan. Results are generally robust to use of single-year values.

15 "General purposes" includes working capital and "general corporate purposes" loans. "Recapitalization" includes debt repayment/consolidation, recapitalization, and debtor-in-possession loans, "Acquisition" includes general or specific acquisition program and LBO loans. The "miscellaneous" category includes securities purchase, stock buy back, and ESOP loans; trade finance, project finance, and real estate loans; credit enhancements, and commercial paper backups. None of these categories includes a large number of loans. 
measure these characteristics with the ratio of the firm's market to book value (proxy for growth opportunities), the R\&D expense to sales ratio, and five-year average sales growth ending with the year of the loan. Market to book is the ratio of the market value of common equity to its book value. R\&D expense is often missing in Compustat; we set such observations to zero, and then include a dummy in regressions for those observations in which it was originally missing (not shown in the results, and never significant).

The influence of outliers is limited by mechanically truncating most variables at the 1st and 99th percentiles (smaller or larger values are set to the values at those percentiles). For a few very noisy variables, such as interest coverage, truncation is at other values, such as the 10th and 90th percentile.

\section{Am Observable risk, not information problems}

Tables 5 and 6 report logit results for variants of a base specification for single and multiple lender loans, respectively. Independent variables include the proxies for observable risk and information problems as well as dummy variables to control for year and industry effects (not shown). The omitted loan purpose category is the general one, including general corporate purposes and working capital loans. The table reports both coefficient values and (in parentheses) the p-values for standard two-tailed tests of statistical significance. Observable risk proxies appear in the top half of the tables and information problem proxies below.

Focusing on the first column, the main overall result is that observable risk proxies have significant predictive power for lender type whereas information problem proxies 
have little power. Both book and market leverage appear in the specification in column 1 (the two are collinear but not perfectly so), and in both single- and multiple-lender cases highly levered firms are significantly more likely to borrow from a finance company than from a bank. The negative and significant coefficients on the EBITDA/sales variable imply that firms with poor cash flow around the time of the loan are also more likely to go to finance companies (but results for cash flow turn out to be sensitive to specification). Comparing leverage and cash flow results across the single- and multiple-lender cases, the coefficient values and significance are remarkably similar, offering some reassurance that the scheme used to classify multiple-lender deals does not introduce too much noise. Results for the loan purpose dummies are less consistent across the two tables, but on the whole do indicate that finance companies are more likely than banks to make loans for what appear to be riskier purposes (restructurings and takeovers) whereas "miscellaneous purpose" loans (a category including commercial paper backups, trade finance, and other purposes) are more likely done by banks.

In contrast, there is little support for a hypothesis that the two types of intermediary serve borrowers posing differing information problems. The coefficients for borrower size (as measured by the log of sales), market to book ratio, sales growth, and years of Compustat coverage are statistically and economically insignificant (though borrower size is statistically significant at the 5 percent level in the multiple-lender case, a glance across the columns shows this result is not robust, and the coefficient value is economically 
small). ${ }^{16}$ The coefficient on the R\&D to sales ratio is negative and statistically significant in the single-lender case, but this result should not be given much weight in interpretation. The result is sensitive to specification, as shown in column 2, where cash flow is omitted. When EBITDAsales is replaced by the probability of negative cash flow (not shown) R\&D is again not significant. When R\&D to sales is represented by a dummy for firms with values above some threshold, such as .03 or .05 , the coefficient not robustly significant. $R \& D$ is never statistically significant in multiple-lender regressions. Most importantly, inspection of the distribution of the R\&D variable revealed that more than two-thirds of both finance company and bank borrowers reported $R \& D$ expense as zero or missing, with the fractions being similar for both. The distributions of nonzero values are also similar across lender types. ${ }^{17}$

Column 3 of the tables reports results when the log of assets replaces the log of sales as the measure of firm size. Although statistically significant or marginally so, the size of the coefficient is again economically small, and its sign differs in the single- and multiple-lender cases. In Figure 1 we display the distribution of borrower sales for loans by banks and finance companies for the single-lender case, and the same distributions for

${ }^{16}$ Of course, the negative results may arise because these variables are poor proxies for information and control problems, but such an interpretation would require an explanation of why other research has implied these to be useful proxies.

17 R\&D might proxy for large volumes of intangible assets and, if finance companies specialize in (tangible) asset-based lending, might indicate firms not well-suited to be finance company borrowers. However, when accounting measures of intangible to total assets are included in the regressions, they are not significant (and have the wrong sign for this argument). 
the multilender case in Figure 2. The distributions are similar, confirming that firm size is not a powerful predictor of lender type and that both types of lenders serve borrowers of a wide variety of sizes.

The qualitative results are robust to a wide variety of changes in specification. The remaining columns of Tables 5 and 6 report a few variants of interest. In column 4 , the market leverage measure is dropped from the model. Unsurprisingly, given the collinearity between market and book leverage, the resulting coefficient on book leverage is larger than in previous columns and even more significant. Coefficients on other variables are largely unaffected, except that cash flow becomes insignificant in the multiple lender case, and the market to book ratio coefficient is negative and significant in the multiple lender case. We attribute the latter to market-to-book's standing in for the marginal influence of market leverage relative to book leverage. ${ }^{18}$ Dropping all the information proxies leaves coefficients and significance for the observable risk proxies basically unchanged (column 5), again with the exception of cash flow, which is insignificant in the single-lender case. Column 6 demonstrates that results for the full specification are similar when the sample is limited to standard-type loans (lines of credit and term loans).

The borrowers in single- and multiple-lender loans differ somewhat (multiple-lender borrowers are larger on average) and a priori one might expect that monitoring methods and institutional specialization might also differ, However, given the insensitivity of lender type to borrower size, it is sensible that results are similar across single- and multiple-

18 Dropping the book leverage measure and retaining market leverage (not reported) yields similar results, except that market-to-book is insignificant. 
lender loans (a similarity that continues throughout the paper).

Other variations in specification (not shown) yielded qualitatively similar results. When included, a dummy for whether a borrower had public debt outstanding was significant only for some multiple-lender loan specifications, and even then the coefficient was economically small, Of three proxies for extent of information problems recently proposed by Calomiris and Himmelberg 1995 (the ratios of cash to fixed capital, long term debt to total debt, and sales to fixed capital), none are robustly significant. ${ }^{19}$ When the sample was restricted to rated firms and dummies for the various ratings were included, their coefficients were in line with the main results (more positive for riskier ratings) but generally insignificant unless leverage was dropped. Proxies for the borrower's use of lease financing were not significant (few sample loans appear lease-related). Of various measures of asset composition, such as the shares of inventory and receivables, fixed capital, intangibles, or cash in total assets, only the coefficient on the fixed capital share is moderately robustly significant. Some observers claim that finance companies are more likely than banks to make loans secured by fixed capital, but in our regressions the variable carries a negative sign, implying that finance companies are less likely to lend to firms with a large share of assets in fixed capital. This result is subject to a wide variety of speculative interpretations; we are reluctant to draw any conclusion from it.

19 Long term to total debt is significant only in the multiple-lender case and when market leverage is included in the model; cash to fixed capital is significant only in the single lender case and when receivables are included in the definition of cash; and sales to fixed capital is significant only in the single-lender case. 


\section{B. Is it control problems? More on cash flow and leverage}

As noted, one possible explanation for specialization in lending is that different lenders specialize in different control problems or control methods. Although the information problem proxies in tables 5 and 6 also are often thought to proxy for control problems, and thus do not support this explanation, the results for leverage and cash flow may be symptomatic of differing agency risks and associated control problems. Two major types of agency problem have been the focus of much of the literature: debtholderstockholder conflicts and insider-outsider conflicts. Different monitoring styles or technologies may be appropriate to the two, or for different degrees of conflict severity. For example, it may be that "asset-based" lending, in which lenders place a high ex ante probability on repayment through seizure of collateral and thus monitor the collateral closely, is most appropriate for high debtholder-stockholder conflict borrowers.

The literature suggests that the debtholder-stockholder conflict is exacerbated by high leverage, whereas the insider-outsider conflict is more a function of free cash flow. A closer look at leverage and cash flow may thus be a helpful indicator of the importance of control problems as determinants of lending specialization. The results for the leverage variables in Tables 5 and 6 are quite strong and are extremely robust to changes in specification, but on further investigation results for cash flow are indicative of a lesser degree of specialization. Tables 7 and 8 report results for variants involving different measures of cash flow. Results in column 1 duplicate those in the first column of the previous tables to make comparison easier. The information problem proxy variables are 
included in the specification but not reported to save space.

EBITDA/assets and EBITDA/interest expense (interest coverage ratio) appear as cash flow measures in columns 2 and 4 , and the measure of the probability of negative cash flow in column 3. As interest coverage is a mixture of pure cash flow and leverage, in column 5 we attempt to control for possible nonlinear relationships between the two by including the square of book leverage and the square root of interest coverage. In column 6 interest coverage is replaced by dummies representing different ranges of the variable (coverage $>10$ is the omitted dummy). The latter is an attempt to capture any nonlinearities in the interest coverage relationship itself. It may be that variations in interest coverage above some threshold value are unimportant (variations in coverage ratios from, say, a value of 3 to a value of 10 might be of little economic importance to lenders but be given large implicit weight by the estimation procedure).

These variations yield decidedly mixed results. In the single-lender case, none of the measures of cash flow are statistically significant aside from EDITDA/sales, whereas in the multiple lender case all are at least marginally significant and have the expected sign (except the interest coverage dummies). In designing the interest coverage dummies, our prior was that the coefficients would increase monotonically in magnitude for each stepdown in coverage. This prior is only very weakly confirmed: coefficients become more positive as coverage decreases to zero, but no coefficient is statistically significant, and the coefficient on the negative-coverage dummy is less than that on the $0-1$ coverage dummy in both cases. 
Figures 3-8 display the distributions of book leverage and two cash flow measures for bank versus finance company loans, separately for single- and multiple-lender cases. Figure 3 shows frequency distributions of borrower book leverage (total debt divided by total debt plus book equity) for single-institution loans. As this picture makes quite evident, finance companies serve higher-leverage borrowers to a much greater degree than banks. About two-thirds of the bank loans in the single-lender sample are to firms with leverage less than 0.5 , whereas only about one-third of finance company loans fall in that range. Conversely, about half of finance company loans are to firms with book leverage exceeding 0.7 . This difference also appears for multiple-lender loans, as shown in Figure 4, although the multiple-lender borrowers are more highly levered on average than single-lender borrowers.

However, Figures 3 and 4 also show that the loan market is not completely partitioned by borrower leverage. Banks and finance companies compete across the spectrum of leverage even though their proportional presence in the high- and lowleverage segments differ.

Figures 5 and 6 show the distributions of interest coverage ratios (EBITDA over interest expense) and Figures 7 and 8 show the distributions of EBITDA/sales. According to the coverage measure, finance companies appear to focus on low cash flow firms, though the relationship appears somewhat nonlinear. In the single-lender case, about one-third of the bank loans are to firms with very high levels of coverage (ratios of 10 or above), whereas less than 5 percent of finance company loans go to such firms. 
Conversely, nearly 50 percent of finance company borrowers had coverage ratios between $\mathrm{O}$ and 2, more than double the concentration of bank loans in that range. In contrast, the distributions of EBITDA/sales are much more similar across lender types. It appears that the interest coverage distribution differences arise mainly from differences in finance company and bank borrower leverage, not differences in cash flow. ${ }^{20}$ The distribution of bank borrowers' cash flow does appear to be shifted a little to the right of the distribution of finance company borrowers' cash flow, but the differences are not nearly so large as for leverage. ${ }^{21,22}$

On the whole, specialization by borrower cash flow appears less pronounced than specialization by leverage. We speculate that the more severe debtholder-stockholder conflicts associated with high leverage may require lenders to engage in different or more intensive control activities ("asset-based" lending), whereas insider-outsider conflicts may

${ }^{20}$ Given two borrowers with similar cash flow but different leverage, the high-leverage firm will naturally have lower interest coverage because their interest expense will be larger.

21 This is somewhat surprising because, as noted previously, conventional wisdom among market participants often labels banks as "cash-flow" lenders and finance companies as "asset-based lenders. It may be that such conventional wisdom has been based on univariate comparisons of interest coverage measures, or perhaps the cash flowlender type relationship can only be captured by a very complex functional form.

22 We also compared distributions of borrower size, leverage, and interest coverage across different types of finance companies (not shown). In particular, we compared bank subsidiaries to all other finance companies, as well as all financial company subsidiaries versus nonfinancial company subsidiaries. In no case did we observe striking differences across different types of finance companies, though it does appear that bank subsidiaries' loans may be a bit more skewed toward lower leverage and higher interest coverage. 
be less sensitive in degree to differences in cash flow or their control may require relatively standard monitoring. However, the control hypothesis is open to three challenges: 1 ) why does different monitoring need to be done by legally different entities? 2) both banks and finance companies serve borrowers across the spectrums of leverage and cash flow, so it would appear both can exert the necessary control when needed; and 3) why are the usual proxies for control problems insignificant? We present a little indirect evidence on lenders' control activities in the next section but more direct evidence is necessary for a definitive test.

\section{A Comparison of Loan Characteristics}

In this section, based on the full sample summarized in Table 3, we compare the types of loans made by banks and finance companies and their stated purposes. In addition, we compare average interest rate spreads, maturities, and the incidence of secured status. We also examine the frequency with which finance companies operate in an agent or lead lender role when loans involve both banks and finance companies. ${ }^{23}$ The comparisons yield more information about dimensions of specialization; provide more support for the hypothesis that finance companies lend to observably riskier borrowers; shed some light on the nature of lender-borrower relationships; and provide a few more facts related to the nature of lenders' monitoring and control activities.

23 By "agent" we mean the lead lender(s) in a multilender deal, the lender(s) with primary responsibility for negotiating terms and administering the loan after issuance. In a single-lender deal, the lender is by definition the agent. A variety of terminology is used in the marketplace to denote lead lenders. 


\section{A. Similar Loan Types, Somewhat Different Purposes}

Table 9 shows the distribution of types of loan in the full sample for single lender facilities involving either (I) a bank or (ii) a finance company, and for multiple lender facilities involving either (iii) banks but not finance companies or (iv) finance companies and perhaps banks or other institutions. As can be seen from the first row, among single lender facilities, there are 822 loans made by finance companies and 7035 made by banks. For both bank as well as finance company loans, a large percentage of these fall into the credit line or term loan categories, Although finance companies show a somewhat higher degree of relative specialization in the term loan category, particularly in the case of multiple lender loans, the distribution of both bank and finance company loans across contract categories is reasonably similar. ${ }^{24}$

Table 10 categorizes loans by finance company parent type. For all four parent types, the two major categories of loans--credit lines and term loans--account for about 90 percent of the total. Moreover, the breakdown between credit lines and term loans does not point to major differences across parent types.

Table 11 shows a breakdown by loan purpose for banks versus finance companies, a dimension along which there appear to be more substantial differences. Where there is only one lender, a little over sixty percent of bank loans are for either general corporate

24 We were somewhat surprised at this result, expecting banks' access to the discount window and to federal funds markets to give them a comparative advantage in lines of credit, which can involve substantial sudden drawdowns by borrowers. Apparently finance companies' own lines of credit and commercial paper market access provide sufficient flexibility in liability management. 
purposes or working capital, whereas less than forty percent of finance company loans fall into this category. Finance company loans, on the other hand, show a higher concentration among restructuring-oriented purposes, such as acquisitions, leveraged buyouts, and debt consolidation. Among multiple-lender loans, such differences are a bit more pronounced. In addition, finance companies are involved in very few commercial paper back-ups.

Table 12 shows a breakdown of finance company loan purposes by finance company parent type. While finance subsidiaries of nonfinancial corporations make a smaller fraction of loans in the general corporate purpose/ working capital category than other finance companies, generally speaking, all the subsidiary types appear to make loans for a variety of purposes.

Recent research has offered evidence that there is more to borrower-lender relationships than the cross-selling of credit and other products often mentioned by practitioners (Rajan 1992; Petersen and Rajan 1994; Berger and Udell 1995). We add to this evidence by examining the extent to which finance companies compete with banks for the agent or lead lender role where both types of institutions participate (table 13). The lead lender likely has the primary relationship with the borrower. If relationships are an important part of private-debt contracting, then finance companies ought to be the lead about in proportion to their market share. If relationships are instead largely associated with cross-selling, banks should dominate the lead role because they offer a much wider array of products. 
Among the 661 loans in which both banks and finance companies are involved, finance companies were the agents almost 20 percent of the time and were co-agents with banks 4 percent of the time. They are agents about in proportion to their dollar share in the 661 loans (27 percent, not shown in table). This suggests that finance companies are quite active in the lead lender role, surprisingly so given that they participate in only 12 percent of our multiple lender facilities (table 7), and given the common view of banks as the main "relationship lenders". Table 13 also shows that finance companies' agenting is not confined to any particular type of loan. However, finance companies that are U.S. or foreign bank subsidiaries are somewhat more likely to be agents than others. ${ }^{25}$ Thus, the implied relationships in many cases may have been forged at the bank holding company level. On the whole, however, it appears finance companies are lead lender often enough that private debt relationships involve more than cross-selling.

\section{B. Prices, Nonprice Terms, and Risk}

Table 14 characterizes some price and nonprice terms of full-sample loans, again broken out into single and multiple lender deals. Panel A displays median spreads between the loan interest rate and LIBOR. Under an assumption of competitive loan markets and costless monitoring, this spread can be viewed as a measure of the residual riskiness of a loan after accounting for the mitigating affects of collateral, covenants and other nonprice terms. To the extent that monitoring is costly and varies with underlying risk, this spread also includes compensation for monitoring as well as the riskiness of the

25 Loans involving bank subs are 55 percent of all loans involving any finance company, but bank subs are the agent in 70 percent of finance-company-agented loans. 
loan (the risk-reducing effects of monitoring and nonprice terms are also included).

For both single- and multiple-lender loans, the median spread charged on finance company loans is substantially greater than that for banks. The second line of Panel A focuses on only those loans made for "standard purposes", working capital or general corporate purposes. Here the difference in medians is a bit larger; the median on singlelender bank loans is 234 basis points while that for finance company loans is 418 basis points. For multi-lender standard-purpose loans, the difference in medians is again near 175 basis points--1 19 versus 280 . Although the corresponding differences in spreads for restructuring- and takeover-related loans (row 3) are narrower, they remain economically significant.

Panel A gives portfolio averages and, since finance companies' loan portfolios are riskier, it is to be expected that they charge higher spreads on average. Panel $\mathrm{B}$ in table 14 shows analogous comparisons after subtracting the contemporaneous average spread on similarly rated bonds from the loan spread for loans to borrowers for which bond ratings could be obtained or estimated. ${ }^{26}$ The difference in medians of such adjusted spreads ought to be narrower because the adjustment, in principle, controls for much of the difference in average borrower risk. As seen from a glance at the table, all the adjusted spreads are negative, implying that credit from both banks and finance companies carries

${ }^{26}$ The average bond spread was computed by subtracting a Treasury yield from the average yield on an index of bonds with a given rating, say BBB, where the Treasury yield was selected to have maturity roughly similar to the average for the index. The spread difference also includes an adjustment for the fact that the bond spread is relative to Treasuries and the loan spread relative to LIBOR. See Carey (1995) for more details. 
somewhat lower interest rates than credit in the bond market. This is unsurprising given that loans are much more frequently secured and typically include more covenants than bonds. The bank-finance company differences in median adjusted spreads are much narrower than those for unadjusted spreads among loans made for standard purposes: they are only about 40 basis points higher for such loans involving finance companies. This implies that, at least for standard purpose loans, much of the difference between finance company and bank borrowers is reflected in their ratings or the determinants thereof, and that finance companies tend to lend to lower-rated firms. ${ }^{27}$ In contrast, the differences in medians of adjusted spreads on restructuring- and takeover-related loans remain about the same as those for unadjusted spreads.

The distinction between the riskiness of borrowers and of loans is important to further interpretation. Although a borrower is likely to default on all debt at once, eventual recovery rates depend on each loan's effective priority, as determined by nonprice terms and perhaps different lenders' ability to play the distressed debt game. Thus an examination of nonprice terms is helpful. ${ }^{28}$

We present statistics for maturity and collateral (almost none of the loans are subordinated). Panel $\mathrm{C}$ of table 14 shows median maturity for full-sample loans. Finance

27 The differences in median unadjusted spreads for the rated subsample of loans are similar to those shown in Panel A of table 14, so the smaller adjusted spread differences in Panel $B$ are not the result of a subsample selection bias.

28 Detailed modeling of the relationships of price and nonprice terms is beyond the scope of this paper. Default probability and recovery rate issues are hard to untangle using the LPC data because of selection mechanisms inherent in the debt contracting process. 
company loans tend to have longer maturities than loans involving just banks. For example, among single-lender loans, bank loan maturities average about 2 years, while finance company loans average about 3 years.

Panel $D$ shows the fraction of loans that are secured..$^{29}$ Single-lender bank and finance company loans are secured 70 and 92 percent of the time, respectively. Smaller fractions of the multiple-lender loans are secured, with the difference between bank-only and finance-company-participating loans somewhat more pronounced. Clearly both types of lender make secured loans very frequently, though finance companies do so more frequently than banks.

As noted in section II, finance companies are often said to monitor collateral closely, whereas banks may obtain a lien on collateral assets but monitor less closely. We do not observe monitoring directly. However, one contracting technology that may be associated with more active monitoring involves limiting the total loan amount outstanding to some fraction of a "borrowing base," an appraised value of specified assets (often inventories and receivables). Loan agreements featuring a borrowing base need not be secured but usually are. We scanned the Des/scan text field for indications that a loan featured a borrowing base and constructed an indicator using methods similar to those for the

${ }^{29}$ The secured indicator differs from that in the LPC database, which yields an upwardbiased estimate of secured proportions. The raw LPC indicator is missing for more than half the observations because LPC codes a loan as secured/unsecured only if they have explicit information about its status and the typical unsecured loan contract simply does not mention collateral. We used information in a descriptive text field to identify loans for which LPC very likely saw the contract and set our indicator to "secured" if the original variable had that value, but "unsecured" either if the original so indicated or if the original was missing and the text field implied LPC saw the contract. 
secured status indicator (footnote 29). Fractions of loans with a nonmissing indicator in each lender-type category that involve a borrowing base stipulation are shown in the last line of Panel $D$ of table 14. As with secured status, both banks and finance companies use this technology frequently but finance companies more so.

Taken together, the price and nonprice terms statistics buttress earlier findings that finance companies lend to riskier borrowers and that at least a very large fraction of the risk difference is associated with leverage. It is not clear from the statistics whether observable risk is the sole difference or if there are differences in control risks or monitoring. On the one hand, the fact that finance company loans are more often secured implies greater monitoring and perhaps greater control problems (Stulz and Johnson 1985), and their higher adjusted spread differences are consistent with higher monitoring costs and/or higher risk. On the other hand, finance company loans are longer-term on average and thus might command a spread premium. In addition, given that finance companies make observably riskier loans, the method for constructing the adjusted spreads might bias their averages upward relative to average bank loan spreads. ${ }^{30}$

\section{Evidence on the Regulatory and Reputational Explanations for Specialization}

Why do finance companies tend to serve observably riskier borrowers? In addition to the hypothesis that banks and finance companies specialize in different kinds of agency

${ }^{30}$ Loan spreads are aggregated by broad rating categories. If finance company loans tend to be clustered at the high-risk end of each category and bank loans at the low-risk end, it would be natural for average finance company loan spreads for each rating to be higher. 
problem control, discussed earlier, we offer two other hypotheses and some evidence. First, bank regulators, in their effort to limit excessive risk taking, may discourage banks from participating fully in the market for loans with high but manageable risk. It is not clear whether the effects of such supervisory action would be felt only at the level of the insured commercial bank or throughout the entire bank holding company (BHC), as holding companies and their nonbank subsidiaries are inspected and supervised by the Federal

\section{Reserve. $^{31}$}

The second hypothesis involves lender reputation as a solution to hold-up problems. Private debt commonly includes covenants that give lenders significant control rights, with some covenants limiting borrower actions in all states of the world and some giving the lender control when the borrower is in distress (Smith and Warner 1977; Berlin and Mester 1992; Carey 1996). Borrowers naturally fear that lenders will extract rents in return for relaxations of control (a hold-up problem) and thus prefer to deal with lenders with reputations for reasonableness. The process by which such valuable reputations are built and maintained is murky, but it seems very likely that refusals to waive covenants and liquidations of borrowers, even when justified, would be costly in terms of the lender's

31 A different element of regulation might also be responsible for specialization. U.S. bank holding companies are permitted to hold up to 5 percent of the voting stock of any firm and 20 percent more of all equity if nonvoting, but banks are permitted to hold equity positions in borrowers (straight or warrants) only as part of restructurings of troubled loans (though they may hold such equity for long periods). Finance companies in general face no such restrictions, and equity positions or warrants are anecdotally a common element of high-risk lending. Finance company subsidiaries of bank holding companies face limits on the amount of voting equity they can hold similar to limits placed on the holding companies, but they may take warrants. 
reputation. Of course, refusing waivers or forcing liquidation is most likely to be warranted for high-risk borrowers. Specialization may support conservation of reputational capital: high risk borrowers go to lenders with a reputation for being tough and such lenders naturally liquidate borrowers and enforce covenants with high frequency given their clientele. Low-risk borrowers go to other lenders, who are better able to maintain good reputations because liquidation and enforcement actions are rarely necessary. It may be important that the two types of lender be separate institutions if it is difficult for borrowers to distinguish reputations of different departments of the same bank, for example. However, there is no particular reason that the low-risk lenders should be banks rather than finance companies---that would be historical accident. ${ }^{32}$

As the reputational hypothesis is complicated, and we offer no model demonstrating the existence of such a mechanism, we view it as a speculation. But is has some anecdotal support, as do the other hypotheses. It should be noted that some gross historical facts may be inconsistent with regulation being the whole story, however. Finance companies have been in business for decades and perhaps predate strict bank regulatory supervision, and finance companies operate abroad, where supervision is often less strict. Presuming that such finance companies also lend to higher-risk borrowers, why did specialization arise if not for a reason integral to the private debt contracting process?

32 There is also no particular reason such a separating equilibrium should involve only two levels of reputation and two institutional types, and indeed some anecdotal evidence about insurance companies' portfolios of private placements might be interpreted as indicating that insurance companies attempt to maintain renegotiation reputations even better than those of banks. 
Using logit models similar to those of section IV, we offer some empirical evidence about the realism of the regulatory and the reputational explanations. We model the choice of lender type for a variety of alternative pairs of types, focusing in each case on whether borrower risk differs. We compare the riskiness of loans made by a set of finance companies that are subsidiaries of U.S. banking organizations with 1 ) loans by banks that are part of the same organizations, 2) loans by finance companies that are not part of banking organizations, and 3) loans made by finance companies that are subsidiaries of foreign banks. All loans (single- and multiple-lender) are pooled for estimation of these models.

Results appear in table 15. In column 1, the dependent variable is 1 if the lending group includes a U.S. bank-affiliated finance company and $O$ if the group includes a U.S. bank that has a finance company affiliate. ${ }^{33}$ If U.S. prudential supervision of banking organizations in general is responsible for specialization by observable risk, these loans should be similar in risk, whereas if prudential supervision of insured banks in particular is responsible, then loans by bank-related finance companies should be riskier than those by affiliated banks. Under the reputational hypotheses, bank-affiliated finance company loans should either resemble those of other finance companies or lie between other finance company loans and bank loans on the risk spectrum, depending on whether the finance company's tough actions harm the affiliated bank not at all, somewhat, or as much

${ }^{33}$ In addition to such banks, the latter lending groups may include only other U.S. banks or nonbanks that are not finance companies. Single-lender loans are of course either bank or finance company loans. 
as if the bank itself had made the loan. The results in column 1 imply that, in fact, loans by affiliated banks and finance companies differ little in observable risk, which is consistent with the version of the regulatory explanation in which $\mathrm{BHC}$-wide regulation is responsible for specialization. The result might be consistent with the reputational explanation, but only if the bank-affiliated finance company subsidiaries obtain little or no reputational separation from the banks, in which case there must be other reasons for the finance companies' existence as a BHC subsidiary.

In column 2 of table 15, finance company subsidiaries of U.S. BHCs are compared with all finance companies not affiliated with banks. The non-bank-related finance companies tend to lend to more highly leveraged borrowers and for riskier purposes. This result is consistent with the regulatory hypotheses, under which unregulated finance companies would make riskier loans. It is also consistent with the reputational hypothesis because tough actions by finance companies not affiliated with banks are less costly in reputational terms.

Technically, foreign bank subsidiaries are regulated like U.S. BHC subsidiaries with respect to their U.S. operations. If BHC-wide regulation is responsible for specialization, finance companies affiliated with foreign banks should resemble U.S. bank affiliates, but they do not, as shown in column 3. Foreign bank affiliates tend to lend to more highly leveraged borrowers. This appears inconsistent with the regulatory hypothesis, as results in column 1 were consistent with the BHC-wide version of that hypothesis, in which case foreign and U.S. bank affiliates should behave similarly It may be that foreign bank 
affiliates are treated differently by regulators de facto. However, this result may also be interpreted as supporting the reputational hypothesis. A substantial share of sample loans made by finance companies affiliated with foreign banks are by previously independent U.S. finance companies bought whole by the foreign bank. Many retain their old name, and thus may achieve very good reputational separation from the bank.

On an assumption that lender names are an essential carrier of reputation, we split bank-affiliated finance companies into those with names similar to those of their parents and those with very different names (column 4). Strikingly, those with similar names tend to lend to less risky borrowers, consistent with their tough actions imposing higher reputational costs on their affiliates. This result must be interpreted with caution, however. Of the couple of dozen sample BHC-affiliated finance companies, only three have names very different from those of their parents (although the three make about 40 percent of the sample loans by such finance companies). Helter Financial, a subsidiary of Fuji Bank, alone made over 30 percent of the subsample loans. When loans by Heller are dropped, the leverage coefficient in column 4 of table 15 becomes insignificant, but of course the sample size is reduced and power may be a problem. Stripping down the specification to include only borrower sales, leverage, and year and purpose dummies increases the sample size to over 400 loans (missing values of variables shrink the usable sample size for the standard specification). For the stripped-down specification (not shown), the leverage coefficient is negative and significant whether loans by Heller are included or not. Given the limitations of the data, we view this name-focused evidence as providing some 
support, but not strong support, for the reputational hypothesis.

On the whole, earlier evidence and that in table 15 offers some support for each of the three hypotheses and some contradictions. Leverage is the most important predictor of lender type, and finance company loans are more often secured, consistent with the hypothesis that finance companies specialize in controlling severe stockholder-debtholder conflicts through asset-based lending. But about two-thirds of bank loans are secured and banks do lend to high-leverage borrowers, so convincing support for this hypothesis would appear to require direct evidence about monitoring techniques. Moreover, it is not clear why asset-based lending must be done in separate corporate entities.

Average borrower riskiness is similar at both U.S. banks and bank-affiliated finance companies, consistent with BHC-wide regulation as the cause of specialization, but foreign bank affiliates more closely resemble the other finance companies, which appears inconsistent.

While the logit results in table 15 are consistent with the reputational explanation, the finding that borrower riskiness is similar at affiliated U.S. banks and finance companies implies that reputation cannot be the whole story. Why would a BHC finance company make loans similar in risk to those of the affiliated bank if the main purpose of the finance company was to take advantage of reputational separation? More research is needed to better identify the reasons for specialization of private debt types and lenders by ex ante observable risk. 


\section{Concluding Remarks}

Recent literature has emphasized that private debt contracts and the financial intermediaries which invest in private debt exist to address contracting problems that are difficult to solve using widely held and traded debt. In some of the literature private debt is referred to generically, with the implication that it is all the same. Other research has suggested that banks in particular are special in their ability to efficiently evaluate and monitor borrowers.

This paper's evidence implies that neither of these simple views is adequate for a full understanding of private debt. It is private market intermediaries in general, not banks in particular, that are special; banks and finance companies appear to lend to equally information-intensive borrowers. However, all private debt and lenders are not the same. We find strong evidence of specialization within the private market, with finance companies tending to serve borrowers with higher observable risk, especially higher leverage. Coupled with the failure of the standard information problem proxies to predict lender type, this result appears inconsistent with a purely information-based understanding of private debt. However, the evidence is more consistent with theories that focus on private lender control of debtholder-stockholder conflicts.

This paper's evidence implies that it is not enough to understand the public-private debt mix, a focus of some very recent research (Diamond 1991; Houston and James 1995a); the mix of varieties of private debt probably also matters. If contract restrictions and monitoring activity differ substantially across the varieties, different mixes of private 
debt types in the capital structure likely have different implications for corporate policy and public security holders.

Although we provide some evidence about possible reasons for the differing specializations of banks and finance companies in corporate lending, including regulatory, monitoring, and reputational mechanisms, more evidence is needed for a full understanding, In general, more research on the types of private debt and private lenders promises to advance understanding of the fundamentals of debt contracting, financial intermediation, and corporate finance. 


\section{References}

Beneish, Messod D., and Eric Press (1993). "Costs of Technical Violation of AccountingBased Debt Covenants," The Accounting Review 68:2, 233-257.

Berger, Allen N., and Gregory F. Udell (1990). "Collateral, Loan Quality, and Bank Risk," Journal of Monetarv Economics 25, pp. 21-42.

Berger, Allen N., and Gregory F. Udell (1995). "Relationship Lending and Lines of Credit in Small Firm Finance, Journal of Business 68:3, 351-381.

Berlin, Mitchell, and Loretta J. Mester (1992). "Debt Covenants and Renegotiation," Journal of Financial Intermediation 2, June.

Billet, Matthew Thayer, Mark J. Flannery and Jon A. Garfinkel (1994). "The Effect of Lender Identity on a Borrowing Firm's Equity Return," Journal of Finance 50:2, June, 699-718.

Black, Fischer (1975). "Bank Funds Management in an Efficient Market," Journal of Einancial Economics, pp. 323-39.

Boczar, Gregory E. (1975). "The Evidence on Competition Between Commercial Banks and Finance Companies," Journal of Bank Research, Summer, 150-154.

Boot, Arnaud W. A., Anjan V. Thakor, and Gregory F. Udell (1 991 ). "Secured Lending and Default Risk: Equilibrium Analysis, Policy Implications and Empirical Results," Economic Journal 101 (May), pp. 458-72.

Booth, James R. (1993). "Loan Collateral Decisions and Corporate Borrowing Costs," working paper (Arizona State University), March.

Booth, James R. (1991). "Contract Costs, Bank Loans, and the Cross-Monitoring Hypothesis" Journal of Financial Economics 31:1, February, 25-41.

Calomiris, Charles and Mark Carey (1994). "Loan Market Competition Between Foreign and U.S. Banks: Some Facts About Loans and Borrowers," in Proceedings of the 30th Annual Conference on Bank Structure and Competition (Chicago: Federal Reserve Bank), forthcoming.

Calomiris, Charles W., and Charles P. Himmelberg (1995). "Investment Banking Costs as a Measure of the Cost of Access to External Finance," working paper (New York: Columbia), October. 
Calomiris, Charles W. and Charles M. Kahn (1991). "The Role of Demandable Debt in Structuring Optimal Banking Arrangements," American Economic Review 81:3, June, 497-513,

Carey, Mark (1995). “Are Bank Loans Misprized?” Working paper, Federal Reserve Board, December.

Carey, Mark (1996). "Financial Covenants, Private Debt, and Financial Intermediation," working paper, Federal Reserve Board, March.

Carey, Mark, Stephen Prowse, John Rea, and Gregory Udell (1993). "The Economics of Private Placements: A New Look," Financial Markets. Institutions and Instruments 2:3.

Chan, Yuk-Shee and George Kanatas (1985). "Asymmetric Valuations and the Role of Collateral in Loan Agreements," Journal of Monev. Credit and Banking 17 (February), pp. 84-95.

Chemmanur, Thomas J. and Paolo Fulghieri (1994). "Reputation, Renegotiation, and the Choice between Bank Loans and Publicly Traded Debt," Review of Financial Studies, Vol. 7, No. 3, Fall, pp. 475-506.

Diamond, Douglas W. (1984). "Financial Intermediation and Delegated Monitoring," Review of Economic Studies 51,393-414.

Diamond, Douglas W. (1991). "Monitoring and Reputation: The Choice Between Bank Loans and Directly Placed Debt," Journal of Political Economv 99, 689-721.

Fama, Eugene (1 985), "What's Different About Banks?" Journal of Monetary Economics 15, January, 29-36.

Fazzari, Stephen M., R. Glenn Hubbard and Bruce C. Peterson (1988). "Financing Constraints and Corporate Investment," BrookingsPapers on Fconomic Activity 1, 141-95.

Flannery, Mark (1 994). "Debt Maturity and the Deadweight Costs of Leverage: Optimally Financing Banking Firms," American Economic Review 84(1), March, 320-31.

Flannery, Mark (1 989). "Capital Regulation and Insured Banks' Choice of Individual Loan Default Risks," Journal of Monetary Economics 24(2), September, 235-58.

Gorton, Gary, and James A. Kahn (1993). "The Design of Bank Loan Contracts, Collateral, and Renegotiation," NBER Working Paper 4273, February. 
Gorton, Gary, and George Pennacchi (1993). "Money Market Funds and Finance Companies: Are They the Banks of the Future?" in Michael Klausner and Lawrence G. White, eds., Structural Change in Banking (Business One Irwin), pp. 173-218.

Harris, Maury (1 979). "Finance Companies as Business Lenders," Federal Reserve Bank of New York Quarterly Review, Summer, 35-39.

Houston, Joel, and Christopher James (1995a). "Bank Information Monopolies and the Mix of Private and Public Debt Claims," working paper, University of Florida, September 26.

Houston, Joel, and Christopher James (1995b). "Banking Relationships, Financial Constraints and Investment: Are Bank Dependent Borrowers More Financially Constrained," working paper, University of Florida, December 7.

James, Christopher (1987), "Some Evidence on the Uniqueness of Bank Loans," Journal of Financial Economics 19, December, pp. 217-35.

Kahan, Marcel and Bruce Tuckman (1993). "Private vs. Public Lending: Evidence from Covenants," working paper, New York University, November.

Kwan, Simon and Willard T. Carleton (1995). "The Role of Private Placement Debt Issuers in Corporate Finance," working paper, Federal Reserve Bank of San Francisco, September 1995.

Kwan, Simon and Willard T. Carleton (1993). "The Structure and Pricing of Private Placement Corporate Loans," working paper (University of Arizona), February.

Mackie-Mason, Jeffrey K. (1990). "Do Firms Care Who Provides Their Financing?" in R. Glenn Hubbard (cd.), Asymmetric Information, Corporate Finance, and Investment (Chicago: University of Chicago Press), pp. 63-103.

Nakamura, Leonard 1. (1991). "Commercial Bank Information: Implications for the Structure of Banking," Federal Reserve Bank of Philadelphia WP 92-1, December.

None, Daniel E. (1994). "Are Foreign Banks Out-Competing U.S. Banks in the U.S. Market?" working paper, Office of the Comptroller of the Currency, February.

Petersen, Mitchell A. and Raghuram G. Rajan (1994). "The Benefits of Lending Relationships: Evidence from Small Business Data," Journal of Finance 49:1, March pp. 3-37. 
Papadimitriou, Dimitri B., Ronnie J. Phillips and L. Randall Wray (1994). "An Alternative in Small Business Finance: Community-Based Factoring Companies and Small Business Lending, Public Policy Brief (Annandale-on-Hudson, New 'York: The Jerome Levy Economics Institute), November 12.

Preece, Dianna C., and Donald J. Mullineaux (1994). "Monitoring By Financial Intermediaries: Banks vs. Nonbanks," Joumal of Financial Services Research 4, 191200 .

Rajan, Raghuram (1992). "Insiders and Outsiders: the Choice Between Informed and Arm's-Length Debt," Journal of Finance 47, 1367-1400.

Remolona, Eli M., and Kurt C. Wulfekuhler (1992). "Finance Companies, Bank Competition, and Niche Markets," Federal Reserve Bank of New York Quarterly Review, Spring/Summer, 25-38.

Sharpe, Steven A and Hien H. Nguyen (1995). "Capital Market Imperfections and the Incentive to Lease," JFE, Vol. 39, pp. 271-294.

Sherman, Michael D. (1993). "Survey of Asset-Based and Other Competitive Lending Activities," The Secured Lerider, November/December, pp. 18-34.

Simon, David P. (1992). "Too Big To Fail and the TED Spread: A Contingent Claims Analysis" (working paper, Federal Reserve Board), September 21.

Simonson, Donald G. (1994). "Business Strategies: Bank Commercial Lending vs. Finance Company Lending," working paper (University of New Mexico), March.

Smith, Clifford W. and Jerold Warner (1979). "On Financial Contracting: An Analysis of Bond Covenants," Journal of Financial Economics 7 (June), pp. 117-61.

Stulz, Rene, and Herbert Johnson (1985). "An Analysis of Secured Debt," Journal of Financial Economics 14, 501-521.

The Secured Lerider (1993). "Asset-Based Lending is Safe and Sound Lending," January/February, pp. 69-75.

Warga, Arthur (1993). "A Fixed Income Data Base," working paper (University of Wisconsin - Milwaukee School of Business Administration), November.

Yelton, Barry D. (1993). "Asset-Based Lending: An Overview," The SecuredLerider May/June 1993, pp. 22-31. 
Table 1: Balance Sheet of Domestic Finance Companies, December 1994 (\$billions)

\begin{tabular}{|c|c|c|c|}
\hline \multicolumn{2}{|l|}{ Assets } & \multicolumn{2}{|c|}{ Liabilities and Net Worth } \\
\hline Receivables, Gross & & & \\
\hline Consumer & 134.8 & Bank Loans & 21.2 \\
\hline Business & 337.6 & Commercial Paper & 184.6 \\
\hline Real Estate & $73.5 \ldots$ & Due to Parent & 50.8 \\
\hline Total & 551.0 & & \\
\hline Less: & & & \\
\hline Reserves for Unearned Income ${ }^{1}$ & $(51.6)$ & $\begin{array}{l}\text { Bonds, Medium-Term } \\
\text { Notes, \& Other Debt }\end{array}$ & 237.2 \\
\hline Reserves for Losses & $(11.6)$ & Other Liabilities & 99.1 \\
\hline Receivables, net & 487.7 & Total Liabilities & 593.0 \\
\hline Other Assets & 180.8 & Equity & 75.5 \\
\hline Total Assets & 668.5 & $\begin{array}{l}\text { Total Liabilities and } \\
\text { Net Worth }\end{array}$ & 668.5 \\
\hline
\end{tabular}

${ }^{1}$ Unearned discounts and service charges on receivables.

Table 2: Finance Company and Commercial Bank Business Credit (\$billions)

Finance Company Business Credit

\begin{tabular}{|c|c|c|c|c|}
\hline Total $^{1}$ & $\begin{array}{c}\text { Auto- } \\
\text { Related }^{2}\end{array}$ & $\begin{array}{l}\text { Equip. } \\
\text { Leasing }\end{array}$ & Other $^{3}$ & $\begin{array}{c}\text { Bank } \\
\text { C\&I } \\
\text { Loans }\end{array}$ \\
\hline
\end{tabular}

Dec 85

157

60

38

60

562

Dec 90

297

92

95

94

806

Dec 94

360

118

109

111

823

Memo: Growth

129

97

189

85

46

Dec. 1985-94

(Percent)

${ }^{1}$ Portions do not sum to total because total business credit of finance companies includes securitized business loans and leases, which are not included in other columns.

${ }^{2}$ Includes auto leasing to businesses and floorplan finance.

3 "Other" includes term loans and revolving lines of credit for retail and wholesale equipment finance and for other short- and intermediate-term business purposes.

${ }^{4}$ Commercial bank C\&I loans include those made by foreign banks to U.S. firms but booked offshore (None, 1995). The lastest period for which an estimate of offshore loans outstanding is available is September 30, 1992. In computing the total for December 1994, we assume the 1992 total for offshore loans was unchanged. 
Table 3: Loan Microdata Sample Characteristics

\begin{tabular}{|c|c|c|c|}
\hline Panel A: Full Sample & All & Single Lender & Multiple Lender \\
\hline Number of Loans & 14735 & 8229 & 6506 \\
\hline Median Loan Size & 30 & 10 & 80 \\
\hline Median Maturity Size & 36 & 27 & 39 \\
\hline \multicolumn{4}{|l|}{ Panel B: Compustat Sample } \\
\hline Number of Loans & 9145 & 5133 & 4012 \\
\hline Median Loan Size & 25 & 10 & 75 \\
\hline Median Maturity Size & 36 & 25 & 37 \\
\hline Median Sales & 232 & 108 & 566 \\
\hline Median Assets & 219 & 91 & 566 \\
\hline \multicolumn{4}{|l|}{ Panel C: Rated Sample } \\
\hline Number of Loans & 4228 & 1655 & 2573 \\
\hline Median Loan Size & 60 & 23 & 102 \\
\hline Median Maturity Size & 36 & 36 & 38 \\
\hline Median Rating & BB & BB- & $\mathrm{BB}$ \\
\hline Median Sales & 635 & 334 & 861 \\
\hline
\end{tabular}

Note: The Compustat sample, which is used in estimating the logit regressions reported below, includes loans to borrowers appearing in Compustat. The rated sample, which was used for certain robustness checks and some spread differences reported in table 14, includes those loans for which a bond rating could be obtained or estimated. Sources for ratings, in order of precedence, are the Warga (1994) public debt database, Compustat, NAIC ratings in the LPC database, and a nonparametric accounting-data-based rating prediction model of our own construction. 
Table 4: Summary Statistics for Variables Proxying for Observable Risk and Information Problems

\begin{tabular}{|c|c|c|c|c|}
\hline Panel A: Observable Risk & Mean & Median & Min & Max \\
\hline Leverage (Book) & 0.524 & 0.516 & 0 & 1 \\
\hline Leverage (Market) & 0.39 & 0.365 & 0 & 1 \\
\hline Interest Coverage & 4.184 & 3.379 & 0 & 10 \\
\hline EBITDA/Assets & 0.117 & 0.126 & -0.34 & 0.39 \\
\hline EBITDA/Sales & 0.137 & 0.115 & -0.73 & 0.73 \\
\hline Probability of negative cash flow & 0.119 & 0.012 & 0 & 0.998 \\
\hline Loan Purpose: Recapitalization & 0.248 & 0 & 0 & 1 \\
\hline Loan Purpose: Acquisition & 0.161 & 0 & 0 & 1 \\
\hline Loan Purpose: General Purposes & 0.533 & 1 & 0 & 1 \\
\hline Loan Purpose: Miscellaneous & 0.058 & 0 & 0 & 1 \\
\hline \multicolumn{5}{|l|}{$\begin{array}{l}\text { Panel B: Information or Control } \\
\text { Problems } \\
\end{array}$} \\
\hline Log Assets & 5.475 & 5.403 & -1.245 & 12.145 \\
\hline Log Sales & 5.47 & 5.451 & -2 & 11.818 \\
\hline Market to Book Ratio & 1.372 & 1.159 & 0.694 & 5.374 \\
\hline 5-Year Sales Growth & 0.302 & 0.116 & -0.15 & 2.22 \\
\hline R\&D to Sales Ratio & 0.016 & 0 & 0 & 0.31 \\
\hline $\begin{array}{l}\text { Number of years of Compustat } \\
\text { data before loan }\end{array}$ & 7.112 & 9 & 0 & 10 \\
\hline \multicolumn{5}{|l|}{ Panel C: Year and Industry } \\
\hline SIC 1000-3999 & 0.563 & 1 & 0 & 1 \\
\hline SIC 4000-4999 & 0.135 & 0 & 0 & 1 \\
\hline SIC 5000-5999 & 0.161 & 0 & 0 & 1 \\
\hline SIC 7000-8999 & 0.141 & 0 & 0 & 1 \\
\hline 1987 & 0.083 & 0 & 0 & 1 \\
\hline 1988 & 0.175 & 0 & 0 & 1 \\
\hline 1989 & 0.164 & 0 & 0 & 1 \\
\hline 1990 & 0.154 & 0 & 0 & 1 \\
\hline 1991 & 0.138 & 0 & 0 & 1 \\
\hline 1992 & 0.18 & 0 & 0 & 1 \\
\hline 1993 & 0.106 & 0 & 0 & 1 \\
\hline
\end{tabular}

Note: Statistics in all panels are for the entire Compustat sample, including both single- and multiple-lender loans. 
Table 5. Lender Type Prediction Model Results, Single Lender Loans

Primary specifications

Dependent variable: 1 if lender is finance company, $O$ if bank $P$-values in parentheses

\begin{tabular}{|c|c|c|c|c|c|c|}
\hline \multirow[b]{2}{*}{ Independent Variable } & \multicolumn{5}{|c|}{ Full Sample Specifications } & \multirow{2}{*}{$\begin{array}{c}\text { TL+REV } \\
\text { Only } \\
6 \\
\end{array}$} \\
\hline & 1 & 2 & 3 & 4 & 5 & \\
\hline Intercept & $\begin{array}{l}-4.058 \\
(.0001)\end{array}$ & $\begin{array}{l}-4.580 \\
(.0001)\end{array}$ & $\begin{array}{l}-3.828 \\
(.0001)\end{array}$ & $\begin{array}{l}-3.629 \\
(.0001)\end{array}$ & $\begin{array}{l}-4.180 \\
(.0001)\end{array}$ & $\begin{array}{l}-4.344 \\
(.0001)\end{array}$ \\
\hline Leverage (Book) & $\begin{array}{l}2.566 \\
(.0001)\end{array}$ & $\begin{array}{l}2.494 \\
(.0001)\end{array}$ & $\begin{array}{c}2.582 \\
(.0001)\end{array}$ & $\begin{array}{l}3.085 \\
(.0001)\end{array}$ & $\begin{array}{l}2.861 \\
(.0001)\end{array}$ & $\begin{array}{l}2.630 \\
(.0001)\end{array}$ \\
\hline Leverage (Market) & $\begin{array}{c}0.602 \\
(.3790)\end{array}$ & $\begin{array}{c}0.850 \\
(.1563)\end{array}$ & $\begin{array}{c}0.686 \\
(.3166)\end{array}$ & & & $\begin{array}{c}0.795 \\
(.2592)\end{array}$ \\
\hline EBITDA/sales & $\begin{array}{l}-1.812 \\
(.0017)\end{array}$ & & $\begin{array}{l}-1.474 \\
(.0121)\end{array}$ & $\begin{array}{l}-1.960 \\
(.0004)\end{array}$ & $\begin{array}{l}-0.553 \\
(.1140)\end{array}$ & $\begin{array}{c}-1.792 \\
(.0021)\end{array}$ \\
\hline Purpose: recap & $\begin{array}{l}0.620 \\
(.0011)\end{array}$ & $\begin{array}{c}0.494 \\
(.0036)\end{array}$ & $\begin{array}{c}0.604 \\
(.0014)\end{array}$ & $\begin{array}{c}0.565 \\
(.0016)\end{array}$ & $\begin{array}{c}0.740 \\
(.0001)\end{array}$ & $\begin{array}{c}0.619 \\
(.0014)\end{array}$ \\
\hline Purpose: takeover & $\begin{array}{l}-0.030 \\
(.9062)\end{array}$ & $\begin{array}{c}0.024 \\
(.9159)\end{array}$ & $\begin{array}{l}-0.011 \\
(.9648)\end{array}$ & $\begin{array}{l}-0.023 \\
(.9261)\end{array}$ & $\begin{array}{c}0.378 \\
(.0460)\end{array}$ & $\begin{array}{l}-0.092 \\
(.7337)\end{array}$ \\
\hline Purpose: misc. & $\begin{array}{l}-1.363 \\
(.0244)\end{array}$ & $\begin{array}{l}-1.439 \\
(.0161)\end{array}$ & $\begin{array}{l}-1.237 \\
(.0418)\end{array}$ & $\begin{array}{l}-1.366 \\
(.0238)\end{array}$ & $\begin{array}{l}-0.794 \\
(.0470)\end{array}$ & \\
\hline Log Sales & $\begin{array}{l}-0.049 \\
(.3517)\end{array}$ & $\begin{array}{l}-0.047 \\
(.3023)\end{array}$ & & $\begin{array}{l}-0.047 \\
(.3344)\end{array}$ & & $\begin{array}{l}-0.033 \\
(.5432)\end{array}$ \\
\hline Log Assets & & & $\begin{array}{l}-0.161 \\
(.0036)\end{array}$ & & & \\
\hline $\begin{array}{l}\text { Market to book } \\
\text { ratio }\end{array}$ & $\begin{array}{l}0.016 \\
(.9245)\end{array}$ & $\begin{array}{l}0.050 \\
(.7155)\end{array}$ & $\begin{array}{l}-0.022 \\
(.8999)\end{array}$ & $\begin{array}{l}-0.038 \\
(.7662)\end{array}$ & & $\begin{array}{c}0.107 \\
(.5551)\end{array}$ \\
\hline $\begin{array}{l}\text { Sales growth } \\
\text { (5-yr avg) }\end{array}$ & $\begin{array}{c}0.234 \\
(.1077)\end{array}$ & $\begin{array}{c}0.155 \\
(.2567)\end{array}$ & $\begin{array}{c}0.264 \\
(.0684)\end{array}$ & $\begin{array}{c}0.162 \\
(.2627)\end{array}$ & & $\begin{array}{c}0.167 \\
(.2688)\end{array}$ \\
\hline R\&D / sales & $\begin{array}{l}-9.754 \\
(.0072)\end{array}$ & $\begin{array}{l}-0.451 \\
(.8384)\end{array}$ & $\begin{array}{l}-10.187 \\
(.0058)\end{array}$ & $\begin{array}{l}-9.792 \\
(.0055)\end{array}$ & & $\begin{array}{l}-8.563 \\
(.0191)\end{array}$ \\
\hline $\begin{array}{l}\text { \# Yrs. Compustat } \\
\text { data before loan }\end{array}$ & $\begin{array}{l}0.074 \\
(.2672)\end{array}$ & $\begin{array}{l}0.070 \\
(.2381)\end{array}$ & $\begin{array}{l}0.105 \\
(.1156)\end{array}$ & $\begin{array}{l}0.040 \\
(.5281)\end{array}$ & & $\begin{array}{l}0.054 \\
(.4357)\end{array}$ \\
\hline Number obs & 2121 & 2559 & 2121 & 2251 & 3505 & 1855 \\
\hline Pseudo- $R^{2}$ & 0.15 & 0.13 & 0.15 & 0.15 & 0.12 & 0.15 \\
\hline
\end{tabular}


Table 6. Lender Type Prediction Model Results, Multiple Lender Loans

Primary specifications

Dependent variable: 1 if lender is finance company, $O$ if bank P-values in parentheses

\begin{tabular}{|c|c|c|c|c|c|c|}
\hline \multirow[b]{2}{*}{ Independent Variable } & \multicolumn{5}{|c|}{ Full Sample Specifications } & \multirow{2}{*}{$\begin{array}{c}\text { TL+REV } \\
\text { Only } \\
6 \\
\end{array}$} \\
\hline & 1 & 2 & 3 & 4 & 5 & \\
\hline Intercept & $\begin{array}{l}-6.827 \\
(.0001)\end{array}$ & $\begin{array}{l}-7.005 \\
(.0001)\end{array}$ & $\begin{array}{l}-6.721 \\
(.0001)\end{array}$ & $\begin{array}{l}-5.463 \\
(.0001)\end{array}$ & $\begin{array}{l}-5.217 \\
(.0001)\end{array}$ & $\begin{array}{l}-6.259 \\
(.0001)\end{array}$ \\
\hline Leverage (Book) & $\begin{array}{l}2.409 \\
(.0109)\end{array}$ & $\begin{array}{l}2.866 \\
(.0002)\end{array}$ & $\begin{array}{l}2.386 \\
(.0114)\end{array}$ & $\begin{array}{l}2.664 \\
(.0001)\end{array}$ & $\begin{array}{l}2.765 \\
(.0001)\end{array}$ & $\begin{array}{l}2.423 \\
(.0138)\end{array}$ \\
\hline Leverage (Market) & $\begin{array}{c}0.895 \\
(.3267)\end{array}$ & $\begin{array}{c}0.299 \\
(.6967)\end{array}$ & $\begin{array}{c}0.839 \\
(.3547)\end{array}$ & & & $\begin{array}{c}0.710 \\
(.4595)\end{array}$ \\
\hline EBITDA/sales & $\begin{array}{l}-1.939 \\
(.0140)\end{array}$ & & $\begin{array}{l}-2.229 \\
(.0055)\end{array}$ & $\begin{array}{l}-0.581 \\
(.3494)\end{array}$ & $\begin{array}{l}-1.346 \\
(.0048)\end{array}$ & $\begin{array}{l}-2.223 \\
(.0101)\end{array}$ \\
\hline Purpose: recap & $\begin{array}{c}1.174 \\
(.0001)\end{array}$ & $\begin{array}{c}1.224 \\
(.0001)\end{array}$ & $\begin{array}{c}1.177 \\
(.0001)\end{array}$ & $\begin{array}{c}1.515 \\
(.0001)\end{array}$ & $\begin{array}{l}1.296 \\
(.0001)\end{array}$ & $\begin{array}{c}1.125 \\
(.0001)\end{array}$ \\
\hline Purpose: takeover & $\begin{array}{c}1.945 \\
(.0001)\end{array}$ & $\begin{array}{l}2.036 \\
(.0001)\end{array}$ & $\begin{array}{c}1.936 \\
(.0001)\end{array}$ & $\begin{array}{c}1.695 \\
(.0001)\end{array}$ & $\begin{array}{c}1.119 \\
(.0001)\end{array}$ & $\begin{array}{c}1.893 \\
(.0001)\end{array}$ \\
\hline Purpose: misc. & $\begin{array}{l}-0.363 \\
(.6329)\end{array}$ & $\begin{array}{l}-0.548 \\
(.4651)\end{array}$ & $\begin{array}{l}-0.358 \\
(.6380)\end{array}$ & $\begin{array}{l}-0.723 \\
(.3313)\end{array}$ & $\begin{array}{l}-1.237 \\
(.0892)\end{array}$ & \\
\hline Log Sales & $\begin{array}{c}0.155 \\
(.0309)\end{array}$ & $\begin{array}{c}0.144 \\
(.0260)\end{array}$ & & $\begin{array}{c}0.073 \\
(.2114)\end{array}$ & & $\begin{array}{c}0.144 \\
(.0503)\end{array}$ \\
\hline Log Assets & & & $\begin{array}{c}0.145 \\
(.0494)\end{array}$ & & & \\
\hline $\begin{array}{l}\text { Market to book } \\
\text { ratio }\end{array}$ & $\begin{array}{c}0.157 \\
(.6247)\end{array}$ & $\begin{array}{c}0.326 \\
(.1525)\end{array}$ & $\begin{array}{c}0.184 \\
(.5670)\end{array}$ & $\begin{array}{l}-0.667 \\
(.0011)\end{array}$ & & $\begin{array}{l}0.146 \\
(.6584)\end{array}$ \\
\hline $\begin{array}{l}\text { Sales growth } \\
\text { (5-yr avg) }\end{array}$ & $\begin{array}{c}0.315 \\
(.1344)\end{array}$ & $\begin{array}{c}0.175 \\
(.3868)\end{array}$ & $\begin{array}{c}0.300 \\
(.1528)\end{array}$ & $\begin{array}{c}0.029 \\
(.8873)\end{array}$ & & $\begin{array}{l}0.276 \\
(.2258)\end{array}$ \\
\hline R\&D / sales & $\begin{array}{l}-11.686 \\
(.1545)\end{array}$ & $\begin{array}{l}-13.357 \\
(.0846)\end{array}$ & $\begin{array}{l}-11.779 \\
(.1500)\end{array}$ & $\begin{array}{l}-8.191 \\
(.2304)\end{array}$ & & $\begin{array}{l}-11.347 \\
(.1776)\end{array}$ \\
\hline $\begin{array}{l}\text { \# Yrs. Compustat } \\
\text { data before loan }\end{array}$ & $\begin{array}{l}-0.099 \\
(.2357)\end{array}$ & $\begin{array}{l}-0.087 \\
(.2401)\end{array}$ & $\begin{array}{l}-0.096 \\
(.2524)\end{array}$ & $\begin{array}{c}0.017 \\
(.8138)\end{array}$ & & $\begin{array}{l}-0.113 \\
(.1863)\end{array}$ \\
\hline Number obs & 2086 & 2455 & 2086 & 2320 & 3039 & 1915 \\
\hline Pseudo- $\mathrm{R}^{2}$ & 0.24 & 0.22 & 0.24 & 0.19 & 0.16 & 0.21 \\
\hline
\end{tabular}


Table 7. Lender Type Prediction Model Results, Single Lender Loans Specifications focusing on cash flow

Dependent variable: 1 if lender is finance company, $O$ if bank $\mathrm{P}$-values in parentheses

\begin{tabular}{|c|c|c|c|c|c|c|}
\hline \multirow[b]{2}{*}{ Independent Variable } & \multicolumn{5}{|c|}{ Full Sample Specifications } & \multirow{2}{*}{$\begin{array}{c}\text { TL+REV } \\
\text { Only } \\
6 \\
\end{array}$} \\
\hline & 1 & 2 & 3 & 4 & 5 & \\
\hline Intercept & $\begin{array}{l}-4.058 \\
(.0001)\end{array}$ & $\begin{array}{l}-4.503 \\
(.0001)\end{array}$ & $\begin{array}{l}-4.303 \\
(.0001)\end{array}$ & $\begin{array}{l}-4.021 \\
(.0001)\end{array}$ & $\begin{array}{l}-3.197 \\
(.0003)\end{array}$ & $\begin{array}{l}-3.976 \\
(.0001)\end{array}$ \\
\hline Leverage (Book) & $\begin{array}{l}2.566 \\
(.0001)\end{array}$ & $\begin{array}{l}2.726 \\
(.0001)\end{array}$ & $\begin{array}{l}2.286 \\
(.0001)\end{array}$ & $\begin{array}{l}2.392 \\
(.0002)\end{array}$ & $\begin{array}{l}-1.049 \\
(.5015)\end{array}$ & $\begin{array}{l}2.727 \\
(.0001)\end{array}$ \\
\hline Leverage (Market) & $\begin{array}{c}0.602 \\
(.3790)\end{array}$ & $\begin{array}{c}0.665 \\
(.3327)\end{array}$ & $\begin{array}{l}0.886 \\
(.1550)\end{array}$ & $\begin{array}{l}0.466 \\
(.5008)\end{array}$ & $\begin{array}{l}0.459 \\
(.5041)\end{array}$ & $\begin{array}{l}0.032 \\
(.9638)\end{array}$ \\
\hline $\begin{array}{l}\text { Leverage (Book) } \\
\text { squared }\end{array}$ & & & & & $\begin{array}{l}2.842 \\
(.0176)\end{array}$ & \\
\hline EBITDA/sales & $\begin{array}{l}-1.812 \\
(.0017)\end{array}$ & & & & & \\
\hline EBITDA/assets & & $\begin{array}{c}0.518 \\
(.5658)\end{array}$ & & & & \\
\hline $\begin{array}{l}\text { Prob neg cash } \\
\text { flow }\end{array}$ & & & $\begin{array}{c}0.377 \\
(.3245)\end{array}$ & & & \\
\hline Interest Coverage & & & & $\begin{array}{l}-0.063 \\
(.1120)\end{array}$ & $\begin{array}{l}-0.175 \\
(.0921)\end{array}$ & \\
\hline $\begin{array}{l}\text { Interest Coverage } \\
\text { square root }\end{array}$ & & & & & $\begin{array}{l}0.320 \\
(.2977)\end{array}$ & \\
\hline$=1$ if $i \operatorname{cov}<0$ & & & & & & $\begin{array}{l}-0.278 \\
(.5466)\end{array}$ \\
\hline$=1$ if $i \operatorname{cov} 0-1$ & & & & & & $\begin{array}{c}0.789 \\
(.0663)\end{array}$ \\
\hline$=1$ if $i \operatorname{cov} 1-3$ & & & & & & $\begin{array}{l}0.193 \\
(.6168)\end{array}$ \\
\hline$=1$ if $i \operatorname{cov} 3-10$ & & & & & & $\begin{array}{l}-0.415 \\
(.2613)\end{array}$ \\
\hline Purpose: recap & $\begin{array}{l}0.620 \\
(.0011)\end{array}$ & $\begin{array}{l}0.655 \\
(.0005)\end{array}$ & $\begin{array}{c}0.452 \\
(.0093)\end{array}$ & $\begin{array}{c}0.628 \\
(.0008)\end{array}$ & $\begin{array}{l}0.606 \\
(.0014)\end{array}$ & $\begin{array}{l}0.633 \\
(.0008)\end{array}$ \\
\hline Purpose: takeover & $\begin{array}{l}-0.030 \\
(.9062)\end{array}$ & $\begin{array}{l}-0.043 \\
(.8638)\end{array}$ & $\begin{array}{l}-0.119 \\
(.6260)\end{array}$ & $\begin{array}{l}-0.004 \\
(.9865)\end{array}$ & $\begin{array}{l}-0.018 \\
(.9445)\end{array}$ & $\begin{array}{l}-0.052 \\
(.8397)\end{array}$ \\
\hline Purpose: misc. & $\begin{array}{l}-1.363 \\
(.0244)\end{array}$ & $\begin{array}{l}-1.271 \\
(.0351)\end{array}$ & $\begin{array}{l}-1.403 \\
(.0192)\end{array}$ & $\begin{array}{l}-1.251 \\
(.0379)\end{array}$ & $\begin{array}{l}-1.250 \\
(.0388)\end{array}$ & $\begin{array}{l}-1.230 \\
(.0424)\end{array}$ \\
\hline Number obs & 2121 & 2121 & 2443 & 2116 & 2116 & 2116 \\
\hline Pseudo- $R^{2}$ & 0.15 & 0.14 & 0.13 & 0.14 & 0.14 & 0.15 \\
\hline
\end{tabular}


Table 8. Lender Type Prediction Model Results, Multiple Lender Loans

Specifications focusing on cash flow

Dependent variable: 1 if lender is finance company, $O$ if bank $\mathrm{P}$-values in parentheses

\begin{tabular}{|c|c|c|c|c|c|c|}
\hline \multirow[b]{2}{*}{ Independent } & \multicolumn{5}{|c|}{ Full Sample Specifications } & \multirow{2}{*}{$\begin{array}{c}\text { TL+REV } \\
\text { Only } \\
6\end{array}$} \\
\hline & 1 & 2 & 3 & 4 & 5 & \\
\hline Intercept & $\begin{array}{l}-6.827 \\
(.0001)\end{array}$ & $\begin{array}{l}-6.992 \\
(.0001)\end{array}$ & $\begin{array}{l}-7.217 \\
(.0001)\end{array}$ & $\begin{array}{l}-5.661 \\
(.0001)\end{array}$ & $\begin{array}{l}-3.080 \\
(.0200)\end{array}$ & $\begin{array}{l}-6.489 \\
(.0001)\end{array}$ \\
\hline Leverage (Book) & $\begin{array}{l}2.409 \\
(.0109)\end{array}$ & $\begin{array}{l}2.132 \\
(.0230)\end{array}$ & $\begin{array}{l}3.020 \\
(.0001)\end{array}$ & $\begin{array}{l}1.291 \\
(.1841)\end{array}$ & $\begin{array}{l}-6.253 \\
(.0087)\end{array}$ & $\begin{array}{c}1.753 \\
(.0668)\end{array}$ \\
\hline Leverage (Market) & $\begin{array}{l}0.895 \\
(.3267)\end{array}$ & $\begin{array}{c}1.043 \\
(.2482)\end{array}$ & $\begin{array}{c}0.087 \\
(.9097)\end{array}$ & $\begin{array}{l}0.456 \\
(.6173)\end{array}$ & $\begin{array}{l}0.144 \\
(.8748)\end{array}$ & $\begin{array}{c}0.119 \\
(.8972)\end{array}$ \\
\hline $\begin{array}{l}\text { Leverage (Book) } \\
\text { squared }\end{array}$ & & & & & $\begin{array}{l}5.762 \\
(.0010)\end{array}$ & \\
\hline EBITDA/sales & $\begin{array}{l}-1.939 \\
(.0140)\end{array}$ & & & & & \\
\hline EBITDA/assets & & $\begin{array}{l}-2.374 \\
(.0534)\end{array}$ & & & & \\
\hline $\begin{array}{l}\text { Prob neg cash } \\
\text { flow }\end{array}$ & & & $\begin{array}{l}2.070 \\
(.0001)\end{array}$ & & & \\
\hline Interest Coverage & & & & $\begin{array}{l}-0.267 \\
(.0001)\end{array}$ & $\begin{array}{l}-0.346 \\
(.0386)\end{array}$ & \\
\hline $\begin{array}{l}\text { Interest Coverage } \\
\text { square root }\end{array}$ & & & & & $\begin{array}{l}0.213 \\
(.6421)\end{array}$ & \\
\hline$=1$ if $\operatorname{cov}<0$ & & & & & & $\begin{array}{c}0.753 \\
(.3506)\end{array}$ \\
\hline$=1$ if Cov 0-1 & & & & & & $\begin{array}{l}0.864 \\
(.2691)\end{array}$ \\
\hline$=1$ if $\operatorname{cov} 1-3$ & & & & & & $\begin{array}{l}0.804 \\
(.2556)\end{array}$ \\
\hline$=1$ if $i \operatorname{cov} 3-10$ & & & & & & $\begin{array}{l}-0.386 \\
(.5684)\end{array}$ \\
\hline Purpose: recap & $\begin{array}{l}1.174 \\
(.0001)\end{array}$ & $\begin{array}{l}1.215 \\
(.0001)\end{array}$ & $\begin{array}{l}1.218 \\
(.0001)\end{array}$ & $\begin{array}{l}1.132 \\
(.0001)\end{array}$ & $\begin{array}{c}1.088 \\
(.0001)\end{array}$ & $\begin{array}{l}1.148 \\
(.0001)\end{array}$ \\
\hline Purpose: takeover & $\begin{array}{l}1.945 \\
(.0001)\end{array}$ & $\begin{array}{l}1.960 \\
(.0001)\end{array}$ & $\begin{array}{l}1.979 \\
(.0001)\end{array}$ & $\begin{array}{l}2.008 \\
(.0001)\end{array}$ & $\begin{array}{l}2.037 \\
(.0001)\end{array}$ & $\begin{array}{c}1.942 \\
(.0001)\end{array}$ \\
\hline Purpose: misc. & $\begin{array}{l}-0.363 \\
(.6329)\end{array}$ & $\begin{array}{l}-0.417 \\
(.5828)\end{array}$ & $\begin{array}{l}-0.559 \\
(.4575)\end{array}$ & $\begin{array}{l}-0.318 \\
(.6758)\end{array}$ & $\begin{array}{l}-0.308 \\
(.6877)\end{array}$ & $\begin{array}{l}-0.259 \\
(.7343)\end{array}$ \\
\hline Number obs & 2086 & 2086 & 2384 & 2086 & 2086 & 2086 \\
\hline Pseudo- $R^{2}$ & 0.24 & 0.23 & 0.23 & 0.25 & 0.25 & 0.25 \\
\hline
\end{tabular}


Table 9: Distribution of Loan Types for Banks and Finance Companies

\begin{tabular}{|c|c|c|c|c|}
\hline \multirow[b]{3}{*}{ Number of Loans } & \multicolumn{2}{|c|}{ Single Lender } & \multicolumn{2}{|c|}{ Multiple Lenders } \\
\hline & Bank & Finance Co. & \multirow{2}{*}{$\begin{array}{r}\text { Banks Only } \\
5119\end{array}$} & \multirow{2}{*}{$\begin{array}{l}\begin{array}{l}\text { Finance Co. } \\
\text { Participating }\end{array} \\
719\end{array}$} \\
\hline & 7035 & 822 & & \\
\hline \multicolumn{5}{|l|}{ Percent in category } \\
\hline Line of Credit & 57 & 51 & 66 & 49 \\
\hline Term Loan & 29 & 40 & 26 & 41 \\
\hline Bridge Loan & 2 & 4 & 3 & 5 \\
\hline Demand Loan & 5 & 2 & 0 & 0 \\
\hline Standby Letter of Credit & 4 & 1 & 4 & 3 \\
\hline Other & 3 & 2 & 0 & 2 \\
\hline \multicolumn{5}{|c|}{$\begin{array}{l}\text { Note: The total number of loans represented, 13695, differs from the size of the full sample, } 14735 \\
\text { because some loans involve neither a bank nor a finance company and some involve mixtures o } \\
\text { banks and other institutional types. The Other loan category includes trade letters of credit, } \\
\text { uncommitted guidance lines, and bankers acceptances. Multiple-lender, finance-company } \\
\text { participating loans include at least one finance company in the lending group and may include banks } \\
\text { and other types of institutions in the group. }\end{array}$} \\
\hline
\end{tabular}

Table 10: Distribution of Loan Types for Finance Companies with Different Parent Types

\begin{tabular}{lcccc}
\hline & \multicolumn{3}{c}{ Parent Type } \\
& U.S. Bank & Foreign & Bank \\
& & $\begin{array}{c}\text { Nonfinancial } \\
\text { Firm }\end{array}$ & $\begin{array}{c}\text { Other } \\
\text { Financial } \\
\text { Firm }\end{array}$ \\
\cline { 2 - 5 } Number of Loans & 349 & 480 & 362 & 160 \\
Percent in Category: & 54 & & 44 & 59 \\
Line of Credit & 35 & 50 & 46 & 33 \\
Term Loan & 7 & 43 & 2 & 4 \\
Bridge Loan & 3 & 3 & 1 & 0 \\
Demand Loan & 1 & 1 & 3 & 0 \\
Standby Letter of Credit & 1 & 2 & 4 & 4 \\
Other & & 1 & \\
\hline
\end{tabular}

Note: Loans made by finance companies with unidentified parents are omitted. The small number of independent finance companies are included in the Other Financial Firm category. The Other loan category includes trade letters of credit, uncommitted guidance lines, and bankers acceptances. 
Table 11: Distribution of Loan Purpose for Banks and Finance Companies

\begin{tabular}{|c|c|c|c|c|}
\hline \multirow[b]{3}{*}{ Number of Loans } & \multicolumn{2}{|c|}{ Single Lender } & \multicolumn{2}{|c|}{ Multiple Lenders } \\
\hline & Bank & Finance Co. & Banks Only & $\begin{array}{l}\text { Finance Co. } \\
\text { Participating }\end{array}$ \\
\hline & 7035 & 822 & 5119 & 719 \\
\hline \multicolumn{5}{|l|}{ Percent in category: } \\
\hline $\begin{array}{l}\text { General corporate } \\
\text { purposes/working capital }\end{array}$ & 61 & 38 & 47 & 18 \\
\hline Takeover and acquisitions & 10 & 14 & 13 & 15 \\
\hline Leveraged buyout & 4 & 13 & 6 & 22 \\
\hline $\begin{array}{l}\text { Debt repayment/ } \\
\text { consolidation }\end{array}$ & 14 & 26 & 22 & 26 \\
\hline Recapitalization & 2 & 4 & 4 & 14 \\
\hline Commercial paper & 1 & -0 & 5 & -0 \\
\hline Other & 7 & 4 & 5 & 5 \\
\hline
\end{tabular}

Table 12: Distribution of Loan Purpose for Finance Companies with Different Parent Types

\begin{tabular}{|c|c|c|c|c|c|}
\hline \multirow[b]{3}{*}{ Number of Loans } & \multicolumn{5}{|c|}{ Parent Type } \\
\hline & U.S. Bank & Foreign & Bank & $\begin{array}{l}\text { Nonfinancial } \\
\text { Firm }\end{array}$ & $\begin{array}{c}\text { Other } \\
\text { Financial } \\
\text { Firm } \\
\end{array}$ \\
\hline & 349 & & 480 & 362 & 160 \\
\hline \multicolumn{6}{|l|}{ Percent in category: } \\
\hline $\begin{array}{l}\text { General corporate } \\
\text { purposes/ working capital }\end{array}$ & 36 & & 30 & 21 & 36 \\
\hline Takeover and acquisitions & 10 & & 16 & 17 & 14 \\
\hline Leveraged buyout & 19 & & 13 & 22 & 13 \\
\hline $\begin{array}{l}\text { Debt repayment/ } \\
\text { consolidation }\end{array}$ & 29 & & 28 & 21 & 28 \\
\hline Recapitalization & 5 & & 9 & 12 & 4 \\
\hline Other & 1 & & 4 & 6 & 5 \\
\hline
\end{tabular}


Table 13: Who is an Agent When Both Banks and Finance Companies Participate?

\begin{tabular}{lrccc}
\hline & \multicolumn{1}{c}{$\begin{array}{c}\text { Number of } \\
\text { loans in } \\
\text { category: }\end{array}$} & $\begin{array}{c}\text { Finance } \\
\text { Company }\end{array}$ & Bank & Both \\
\cline { 2 - 5 } Number of Loans & 661 & 121 & 514 & 26 \\
\cline { 3 - 5 } & 329 & Percent in loan type category: & 46 & 4 \\
Line of credit & 279 & 20 & 79 & 0 \\
Term Loan & 31 & 17 & 81 & 9 \\
Bridge Loan & 22 & 19 & 82 & 46 \\
Standby letter of credit & & 9 & & \\
\hline
\end{tabular}


Table 14: Loan Terms: Spreads, Maturity and Security

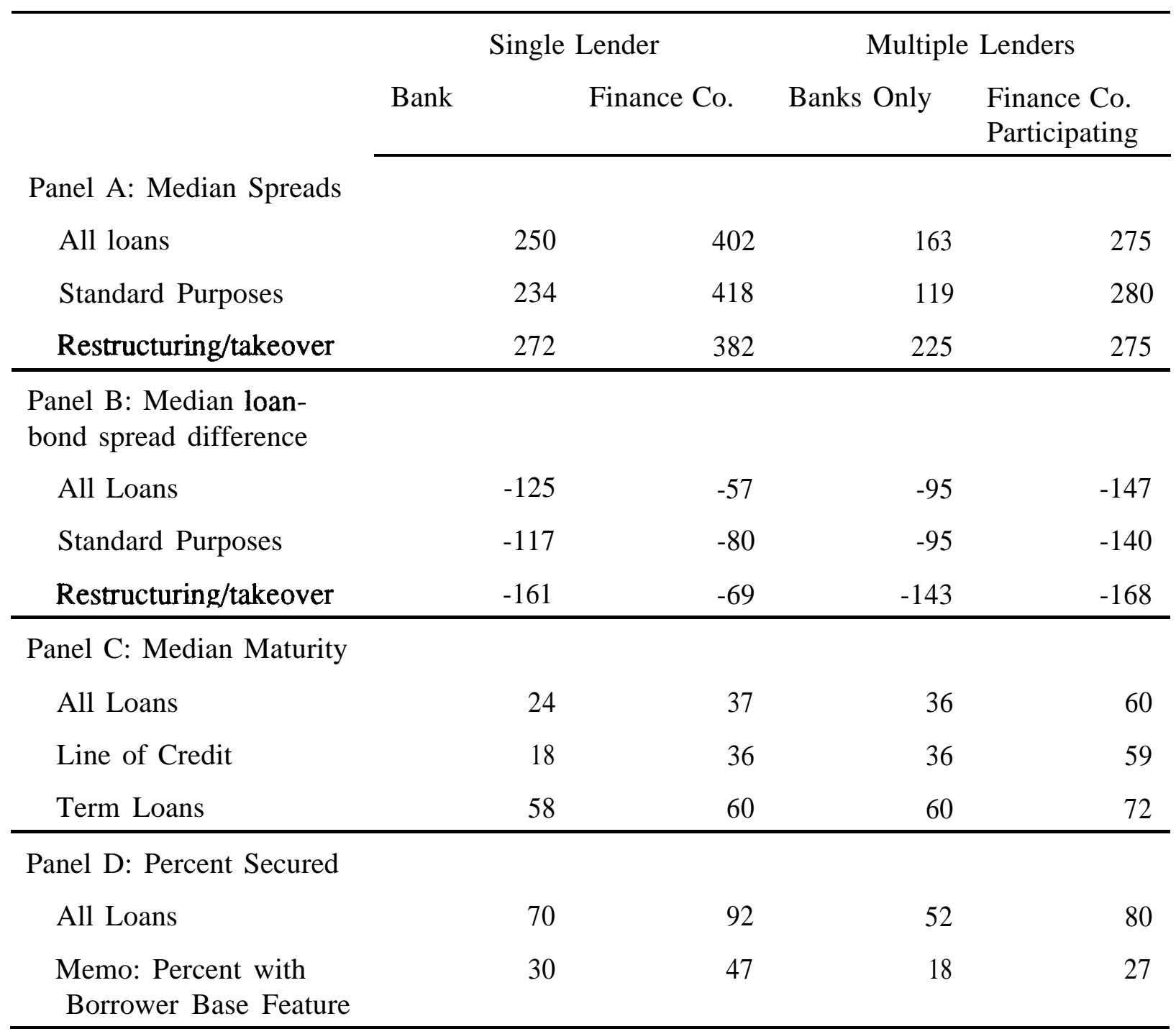


Table 15. Lender Type Prediction Model Results, All Numbers of Lenders Specifications focusing on reasons for specialization

Dependent variable varies by column, see headings P-values in parentheses

\begin{tabular}{|c|c|c|c|c|}
\hline Independent Variable & $\begin{array}{l}1=\text { US BHC } \\
\text { finance co } \\
0=\text { US bank } \\
\text { affiliated w/ } \\
\text { finance co }\end{array}$ & $\begin{array}{c}1=\text { US BHC } 1 \\
\text { finance Co } \\
0=\text { nonBHC } \\
\text { finance co }\end{array}$ & $\begin{array}{l}=\mathrm{US} \mathrm{BHC} \\
\text { finance co } \\
\vdots 0=\text { foreign } \\
\mathrm{BHC} \\
\text { finance co }\end{array}$ & $\begin{array}{l}\text { tC finance co } \\
=\text { name similar } \\
\text { to affil. bank } \\
0=\text { different } \\
\text { name }\end{array}$ \\
\hline Intercept & $\begin{array}{c}-1.444 \\
(.2235)\end{array}$ & $\begin{array}{l}4.050 \\
(.0300)\end{array}$ & $\begin{array}{c}5.231 \\
(.0124)\end{array}$ & $\begin{array}{c}0.815 \\
(.6579)\end{array}$ \\
\hline Leverage (Book) & $\begin{array}{l}0.516 \\
(.2833)\end{array}$ & $\begin{array}{l}-2.919 \\
(.0016)\end{array}$ & $\begin{array}{l}-4.390 \\
(.0001)\end{array}$ & $\begin{array}{l}-2.293 \\
(.0013)\end{array}$ \\
\hline EBITDA/sales & $\begin{array}{l}-0.620 \\
(.4782)\end{array}$ & $\begin{array}{l}0.926 \\
(.5479)\end{array}$ & $\begin{array}{l}-1.552 \\
(.3483)\end{array}$ & $\begin{array}{c}0.306 \\
(.8306)\end{array}$ \\
\hline Purpose: recap & $\begin{array}{c}0.430 \\
(.1269)\end{array}$ & $\begin{array}{l}-1.287 \\
(.0040)\end{array}$ & $\begin{array}{c}0.012 \\
(.9777)\end{array}$ & $\begin{array}{l}-0.576 \\
(.1325)\end{array}$ \\
\hline Purpose: takeover & $\begin{array}{c}0.780 \\
(.0150)\end{array}$ & $\begin{array}{l}-1.386 \\
(.0122)\end{array}$ & $\begin{array}{l}0.391 \\
(.5210)\end{array}$ & $\begin{array}{l}-1.142 \\
(.0409)\end{array}$ \\
\hline Log Sales & $\begin{array}{l}-0.250 \\
(.0012)\end{array}$ & $\begin{array}{l}-0.745 \\
(.0001)\end{array}$ & $\begin{array}{l}-0.280 \\
(.0930)\end{array}$ & $\begin{array}{l}0.138 \\
(.3468)\end{array}$ \\
\hline $\begin{array}{l}\text { Market to book } \\
\text { ratio }\end{array}$ & $\begin{array}{l}-0.292 \\
(.1987)\end{array}$ & $\begin{array}{c}0.183 \\
(.6431)\end{array}$ & $\begin{array}{l}-0.296 \\
(.3761)\end{array}$ & $\begin{array}{c}0.426 \\
(.1670)\end{array}$ \\
\hline $\begin{array}{l}\text { Sales growth } \\
\text { (5-yr avg) }\end{array}$ & $\begin{array}{l}-0.700 \\
(.0439)\end{array}$ & $\begin{array}{l}-1.180 \\
(.0031)\end{array}$ & $\begin{array}{l}-0.678 \\
(.0387)\end{array}$ & $\begin{array}{l}-0.197 \\
(.4956)\end{array}$ \\
\hline R\&D / sales & $\begin{array}{c}-7.283 \\
(.1945)\end{array}$ & $\begin{array}{l}-17.257 \\
(.0809)\end{array}$ & $\begin{array}{l}5.554 \\
(.6788)\end{array}$ & $\begin{array}{l}9.779 \\
(.4470)\end{array}$ \\
\hline $\begin{array}{l}\text { \# Yrs. Compustat } \\
\text { data before loan }\end{array}$ & $\begin{array}{c}0.123 \\
(.2878)\end{array}$ & $\begin{array}{l}0.411 \\
(.0095)\end{array}$ & $\begin{array}{c}0.079 \\
(.6528)\end{array}$ & $\begin{array}{c}0.014 \\
(.9311)\end{array}$ \\
\hline Number obs & 1207 & 279 & 215 & 215 \\
\hline Psuedo- $R^{2}$ & 0.11 & 0.41 & 0.28 & 0.10 \\
\hline
\end{tabular}

All miscellaneous-purpose loans were omitted from the samples to eliminate sparse-sample convergence problems related to purpose dummies. 
Figure 1: Distribution of Borrowers'

Fraction of Loans Annual Sales (Single Lender)
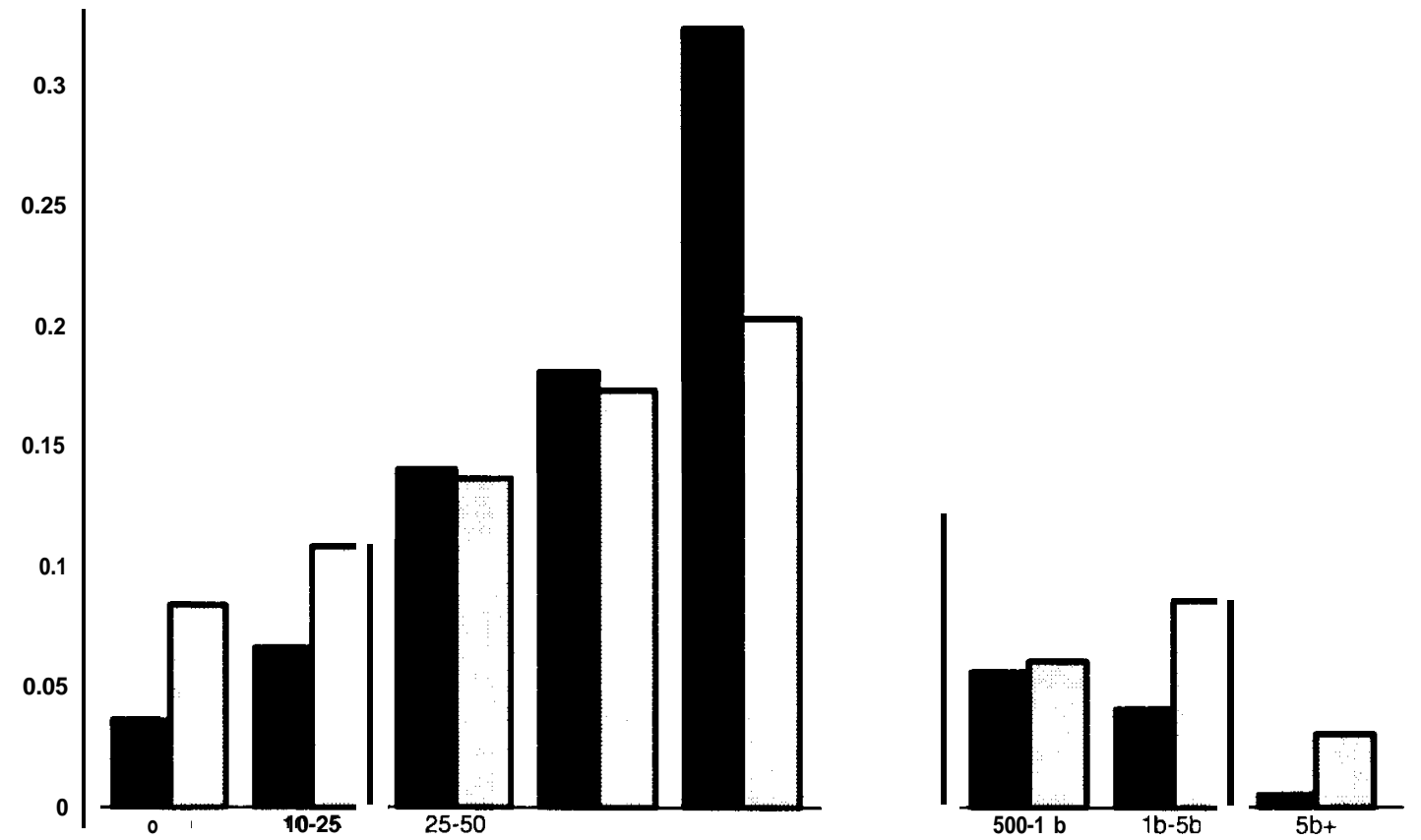

Sales, \$ millions 
Figure 2: Distribution of Borrowers'

Fraction of Loans Annual Sales (Multiple Lender)

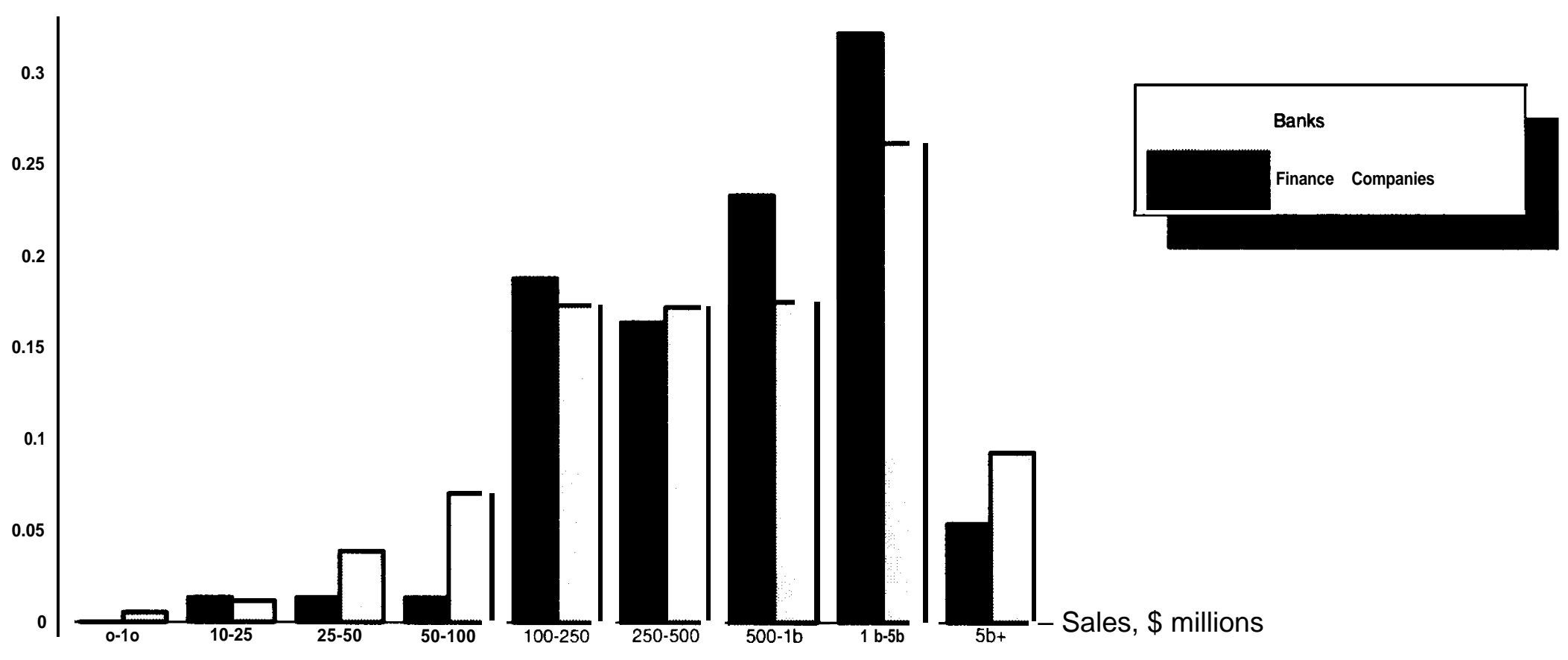




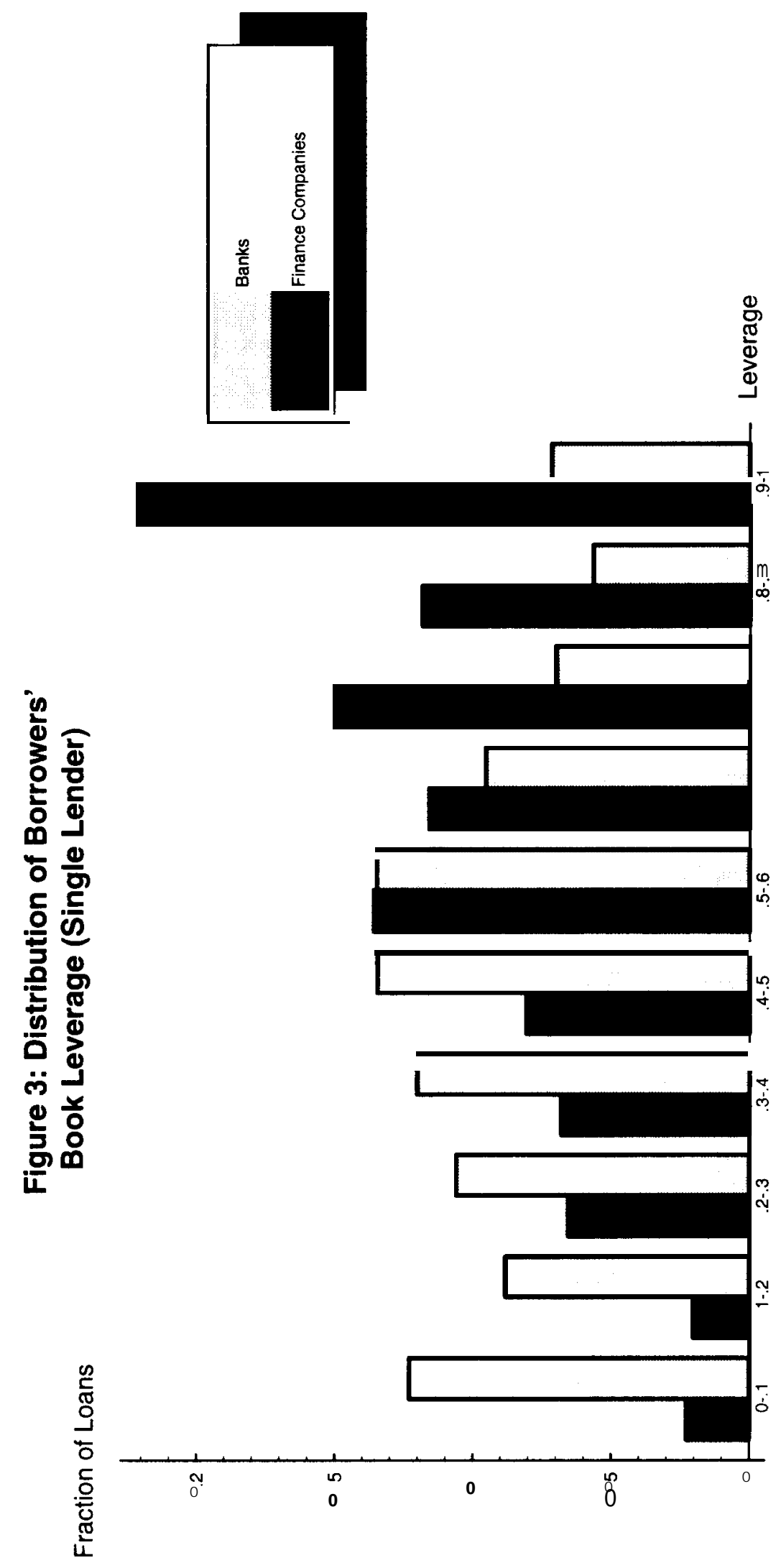


Figure 4: Distribution of Borrowers'

Fraction of Loans

Book Leverage (Multiple Lender)

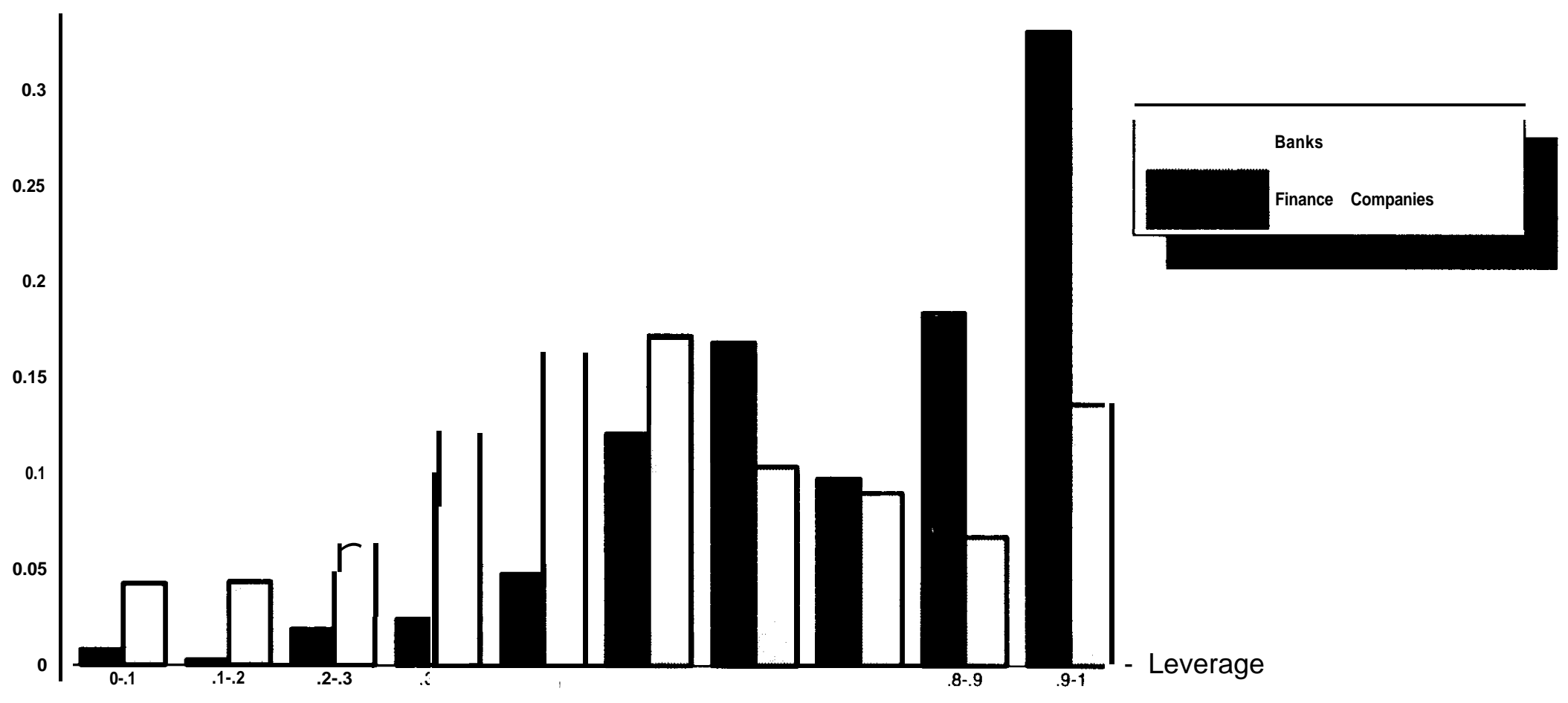


Figure 5: Distribution of Borrowers'

Interest Coverage (Single Lender)

Fraction of Loans

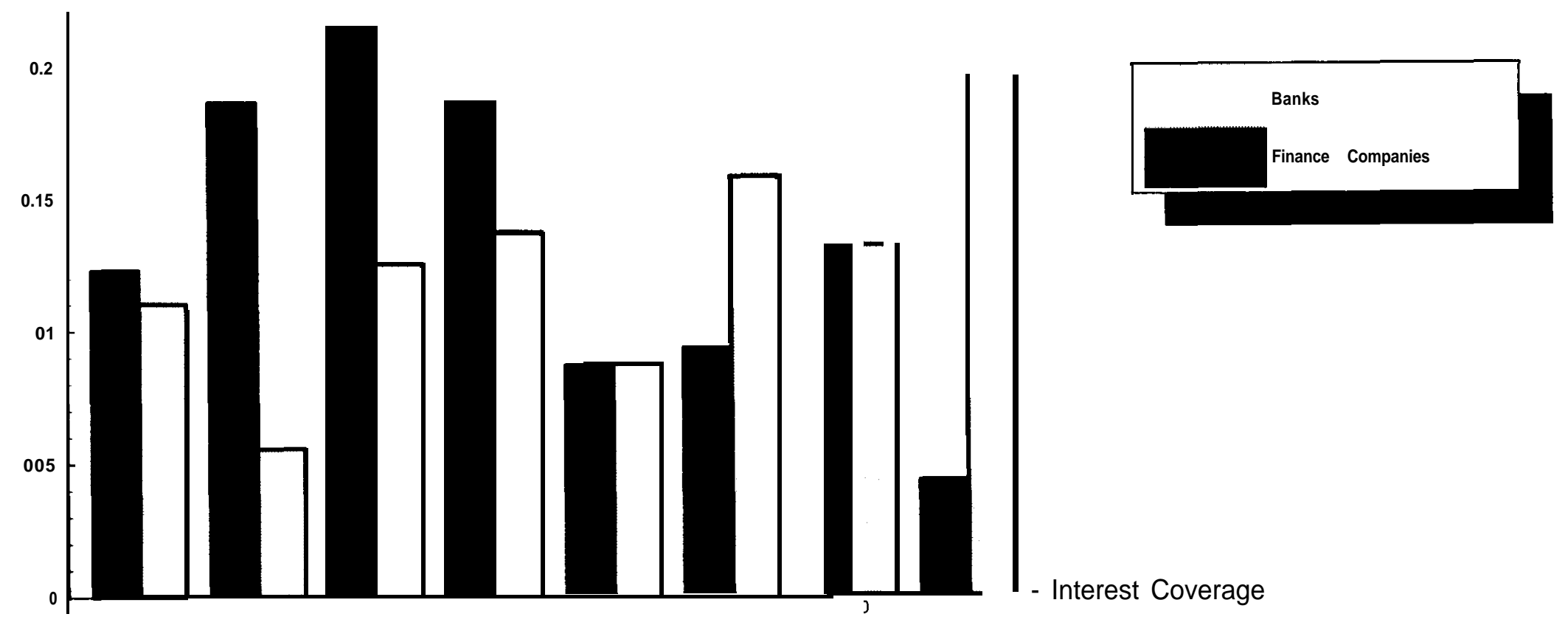


Figure 6: Distribution of Borrowers'

Fraction of Loans Interest Coverage (Multiple Lender)
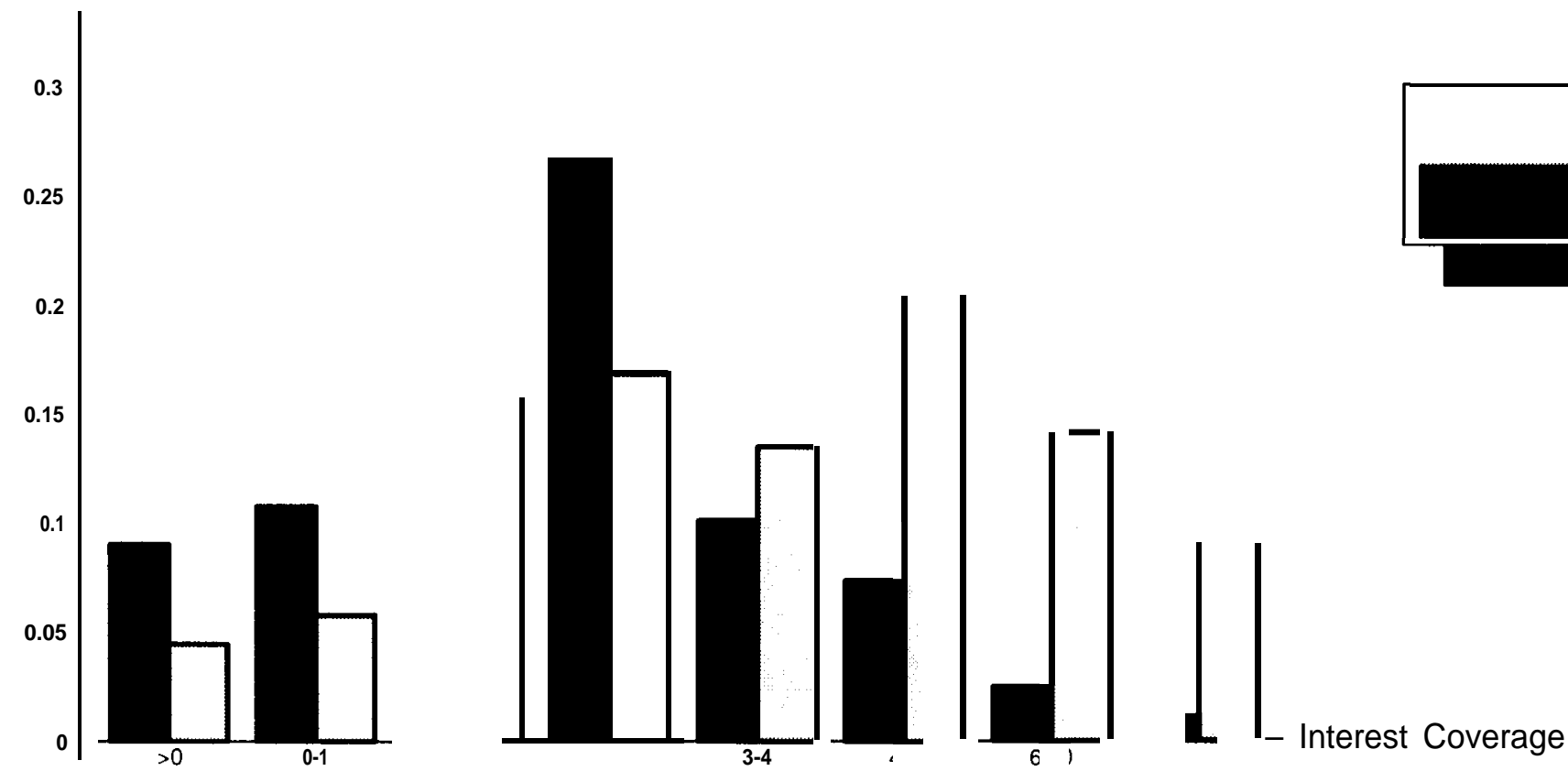

Finance Companies 
Fraction

of Loans

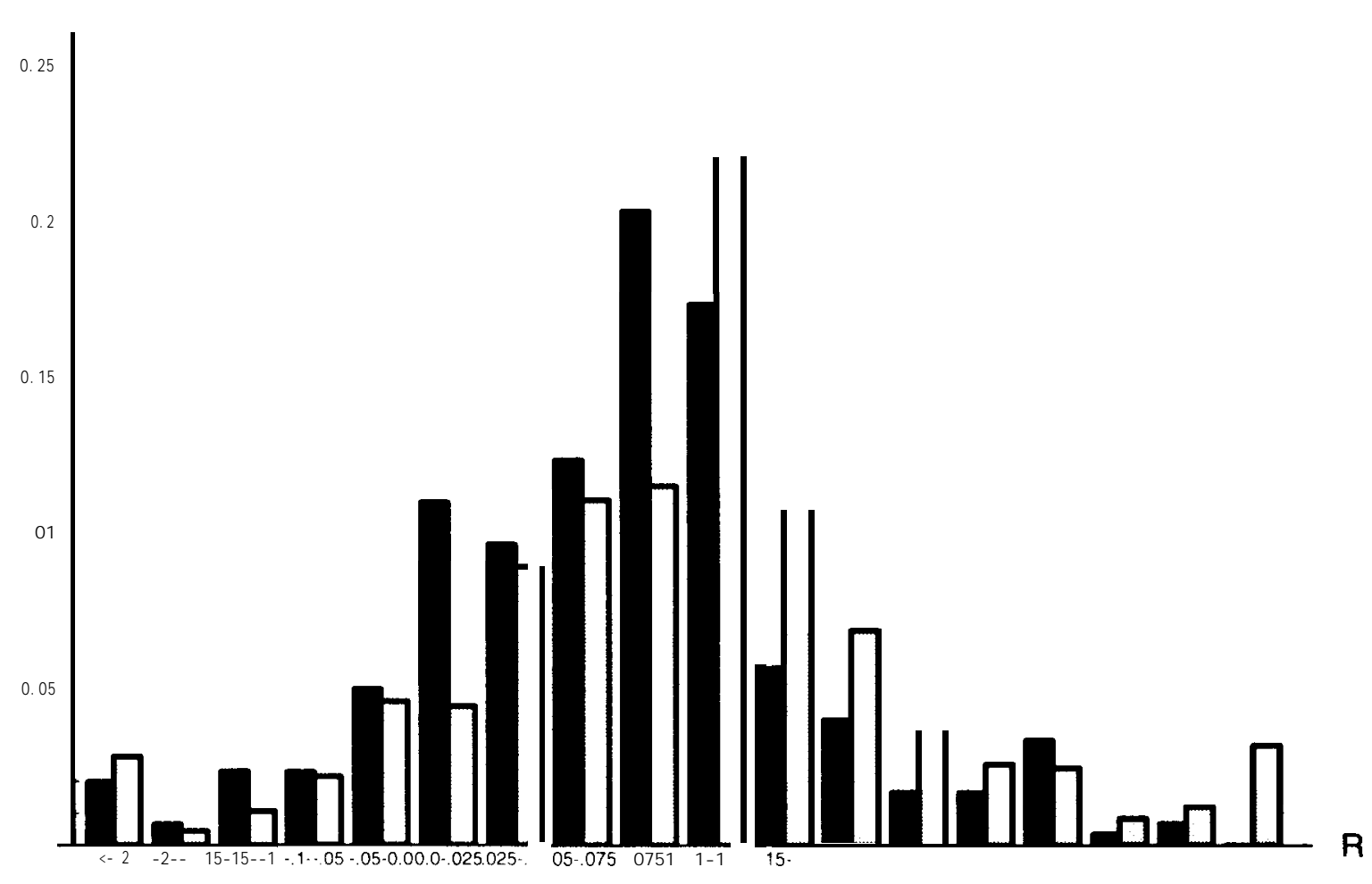

Figure 7: Distribution of Borrowers'
Return-on-Sales (Single Lender)

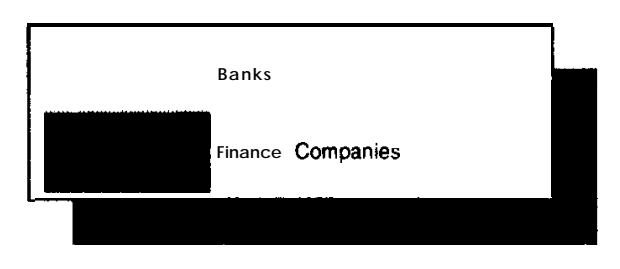


Figure 8: Distribution of Borrowers'

Return-on-Sales (Multiple Lender)

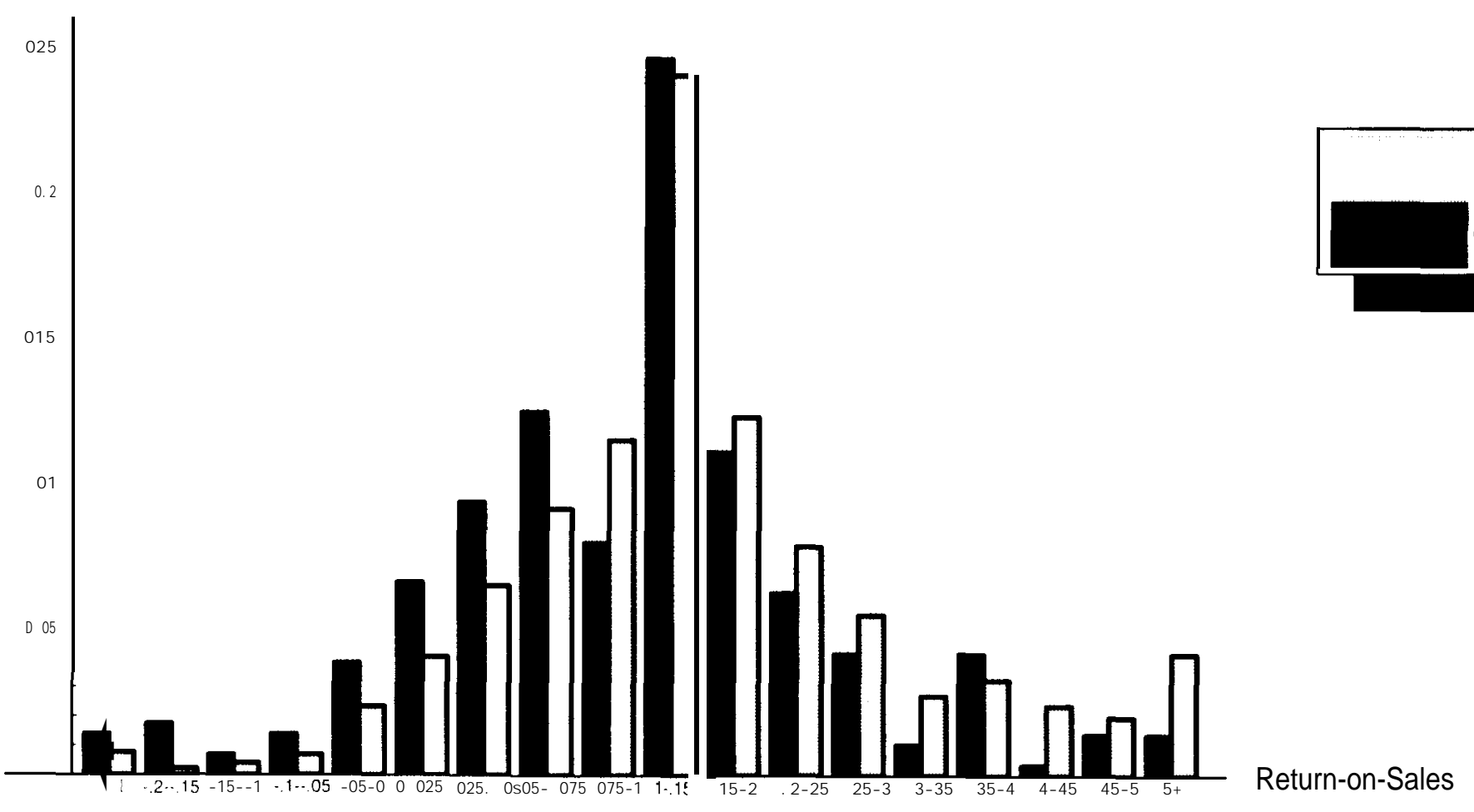

